\title{
ZANIK UCZUĆ METAFIZYCZNYCH JAKO PRZYCZYNA KRYZYSU KULTURY
}

\begin{abstract}
Jacek Breczko
Sądzę, że niewątpliwemu postępowi w technice towarzyszy obecnie na Zachodzie kryzys kultury. Kwestią sporną jest jego nasilenie; można bronić poglądu, że co się rozwija, to się po części rozkłada, kryzys jest więc permanentny i jest funkcją postępu, ale też nie można odrzucić trafności diagnozy katastroficznej. Kryzys ten ma niewątpliwie różne przejawy i różne źródła. W artykule koncentruję się na źródle wskazanym przez S. I. Witkiewicza: na zaniku Metafizycznego Poczucia Dziwności Istnienia oraz na jego skutkach. Diagnozę Witkacego - która wydaje mi się w ogólnych zarysach trafna - próbuję zastosować do czasów współczesnych. Uważam, że zanik uczuć metafizycznych jest obecnie stymulowany nie tylko coraz wygodniejszym i bardziej szczelnym „kokonem cywilizacyjnym”, ale też „zapomnieniem o śmierci” (śmierć staje się tabu $\mathrm{w}$ kulturze) oraz panowaniem $\mathrm{w}$ nauce naturalizmu metodologicznego, który powoduje, żeświat przestaje się jawić jako „dziwny”, „tajemniczy”. Wszystko to zaś uszkadza, „wyjaławia” wyższe piętra kultury, czyli destrukcyjnie wpływa na działalność elit artystycznych, filozoficznych i religijnych.
\end{abstract}

Słowa kluczowe: kultura, kryzys, katastrofizm, S. I. Witkiewicz

Wyrzekanie się [...] uczuć metafizycznych czyni nas, mimo całego uspołecznienia, bardziej podobnymi do zwierząt, niż nam się wydaj

S. I. Witkiewicz

W IX i XX w. powszechnie się myślało, że za postęp cywilizacji płaci się uszczerbkiem wartości duchowych. Dlatego ci, co nie nadążają, mieli być $\mathrm{w}$ zamian poczciwsi i bogobojni.

Jerzy Jedlicki

JACEK BRECZKO, doktor habilitowany, Studium Filozofii i Psychologii Człowieka, Uniwersytet Medyczny w Białymstoku, Polska; adres do korespondencji: ul. Szpitalna 37, 15-295 Białystok. E-Mail: breczko@poczta.onet.p1 


\section{Kryzys kultury? Uwagi wstępne}

Można mieć wątpliwości, czy mamy obecnie do czynienia $\mathrm{z}$ kryzysem zachodniej kultury (bo o nią tu głównie chodzi). Czymś niewątpliwym jest jednak jej gwałtowna przemiana; jest ona na tyle rozległa i dogłębna, że można wręcz mówić o mutacji kulturowej. Czesław Miłosz zauważył, że znajdujemy się „w środku cyklonu” i trudno silić się w tym momencie na „zgrabne diagnozy”. Myślę podobnie i dlatego w tekście tym będą przeważać tryby warunkowe i przypuszczenia, a nie „sądy ostateczne”.

Zacznijmy od sprawy podstawowej. Skoro zgodzimy się, że w kulturze dokonuje się obecnie gwałtowna zmiana, to pojawia się pytanie, czy jest to zmiana na lepsze, czy na gorsze. Tylko w tym drugim przypadku byłby to kryzys. Aby jednak ocenić, czy jest to zmiana na lepsze, czy na gorsze, musimy mieć miarę, kryterium oceny.

Są więc w istocie trzy możliwości. Pierwsza: nie istnieje taka miara. Każdy może mierzyć (oceniać) stan kultury ze swojego punktu widzenia i każdy punkt widzenia jest „równie dobry”, czyli żaden punkt widzenia nie jest wyróżniony. Jednemu się podoba, drugiemu się nie podoba; istnieją tylko miary subiektywne, nie istnieje miara obiektywna i rzetelna. Byłoby to rozwiązanie relatywistyczne, wykluczające możliwość stwierdzenia, czy jest kryzys, czy postęp. Inną odmianą takiego podejścia - tym razem nie $\mathrm{w}$ duchu relatywizmu, ale sceptycyzmu - byłoby przyznanie, że być może nawet miara istnieje, ale przedmiot jest zbyt złożony, aby dało się ją zastosować (kultura jest zbyt skomplikowana i dynamiczna, aby dało się ją zmierzyć).

Druga możliwość: istnieje taka miara i wskazuje ona, że jest to zmiana na lepsze, że mamy do czynienia ze wzrostem, z rośnięciem kultury, a nie z kryzysem. Można, na przykład, wskazywać, że kultura staje się coraz bardziej różnorodna i zmienna; kiedyś panowała przez dłuższy czas jedna moda, teraz równocześnie panuje kilka mód i te mody błyskawicznie się zmieniają. Co więcej, rośnie liczba poetów, pisarzy, rzeźbiarzy, malarzy, filmowców, programistów, dizajnerów, a zatem rośnie liczba twórców i aktywnych odbiorców kultury i to jest dobre.

I trzecia możliwość: istnieje taka miara i wskazuje ona, że to zmiana na gorsze, że kul-tura psuje się, karleje, że mamy do czynienia z tendencją spadkową, czyli $\mathrm{z}$ kryzysem. Warto odnotować, że w przypadku diagnozy optymistycznej, czyli stwierdzenia wzrostu i

${ }^{1}$ Cz. Miłosz, Ziemia Ulro, Znak, Kraków 1994, s. 269. 
postępu, wydaje się dominować kryterium ilościowe, natomiast w przypadku diagnozy pesymistycznej stosuje się raczej kryterium jakościowe. W tekście tym - jak zresztą wskazuje na to tytuł - skłaniam się do diagnozy pesymistycznej, czyli że trafna jest owa trzecia możliwość.

Chciałbym jednak od razu, na wstępie, uczynić dwa zastrzeżenia. Otóż w przypadku zdiagnozowania postępu lub regresu, należy liczyć się z błędem perspektywy, czyli zbyt krótkiej skali czasowej. Niekiedy regres jest wstępem do postępu i wzlotu (jak w przypadku skoków narciarskich), niekiedy zaś postęp i wzlot jest wstępem do upadku (jak w przypadku działań artystycznych wspomaganych narkotykami). I zastrzeżenie kolejne: trafna wydaje się uwaga, że kulturę europejską, a następnie zachodnią, odróżnia od większości kultur jej dyna-mika, zmienność, antyschematyczność, samokrytycyzm i otwartość. To zaś, co się rozwija, to się rozkłada. Rozkład bywa więc funkcją postępu (wzrostu, zdrowia). W kulturze zachodniej występują - jak to określił Józef Maria Bocheński - różne „zgniłki”, relatywiści i sceptycy, którzy przyczyniają się do zmian. Można więc stwierdzić, że kultura zachodnia jest w permanentnym kryzysie i jest to właśnie objaw zdrowia i postępu. To - jak sądzę - trafne spostrzeżenie, ale tylko przy bardzo wysokim stopniu ogólności. Kiedy jednak zrezygnujemy kwantyfikatora ogólnego i przyjrzymy się bliżej procesom kulturowym, które rozegrały się w Europie na przestrzeni dziejów, możemy dostrzec i epoki, i miejsca, gdzie procesy rozkładowe zdecydowanie przeważały i doprowadzały do upadku lub przewlekłego kryzysu (kiedy liczba „zgniłków” przekraczała pewien poziom, stawało się to niebezpieczne dla zwartości, spoistości społeczeństwa). Wymieńmy, dla przykładu, późny Rzym, Włochy renesansowe czy Republikę Weimarską.

\section{Postęp techniczny a kryzys kultury}

Kryzys kultury może budzić wątpliwości, bezsporny natomiast wydaje się postęp w sferze technicznej, cywilizacyjnej ${ }^{2}$. Jeśli jednak

\footnotetext{
2 Pojawiają się, co prawda, głosy, że postęp techniczny nie jest oczywisty, bo w pewnych dziedzinach archaiczne kultury były dużo bardziej zaawansowane niż my (paleolityczne siekierki były podobno ostrzejsze niż współczesne noże), albo że prosta technika dawała wspaniałe efekty związane z wygodą i pięknem życia, jak w przypadku kultur pasterskich, na przykład Hucułów (pogląd Jerzego Stempowskiego). Wydaje się jednak, że to błędne argumenty; postęp technologiczny należy mierzyć całościowo, nie tylko ostrością ostrza (laser zresztą „wygrywa” z najostrzej zatemperowanym kamieniem); lepsze zaś efekty prostszej techniki i cywilizacji dotyczą postępu w ,jakości ży-
} 
uznamy, że w kulturze jest kryzys, to pojawia się pytanie, czy te dwa procesy - tendencja spadkowa $\mathrm{w}$ kulturze i tendencja wzrostowa $\mathrm{w}$ sferze technicznej - są od siebie niezależne, czy też mają ze sobą jakiś związek, w jakiś sposób oddziałują na siebie. Otóż sądzę, że istnieje tutaj zależność i to zależność - na pierwszy rzut oka - paradoksalna; sądzę mianowicie, że postęp techniczny napędza i pogłębia kryzys kultury ${ }^{3}$. Zanim jednak wskażę, na czym - moim zdaniem - „ten napęd” polega (a jest on złożony i wielopoziomowy), chciałbym naszkicować dwie możliwości.

Pierwsza: postęp techniczny generuje regres w kulturze w sposób konieczny. Jest to zależność absolutna i nieodwracalna. Mielibyśmy w tym przypadku do czynienia z rodzajem konieczności dziejowej, która prowadziłby - niczym fatalizm grecki - do katastrofy w kulturze. Byłby to zatem - w ogólnych zarysach - schemat katastrofizmu kulturowego. Schemat taki można znaleźć u Stanisława Ignacego Witkiewicza. Uważa on, że postęp $\mathrm{w}$ jakości życia i w uspołecznieniu (który wiąże się $\mathrm{z}$ postępem technicznym) jest krzywą rosnącą $\mathrm{w}$ nieskończoność (a w każdym razie do osiagnięcia stadium społecznego homogenu); natomiast krzywa poziomu kultury początkowo rośnie wraz z krzywą uspołecznienia, następnie jednak - kiedy społeczne szczęście zaczyna wypleniać mądrość - krzywa ta zaczyna spadać aż do zaniku kul-tury wyższej, czyli do zera. Używając metafory biblijnej: rozwój cywilizacji doprowadzi ludzkość do uspołecznionego, bezpiecznego, wygodnego i szczęśliwego raju, a w raju nie ma miejsca na „niepokój twórczy”, czyli - w istocie - na twórczość.

cia", który to postęp zaiste jest dyskusyjny, a nie postępów w samej technice. I po trzecie, zaawansowana technika może być wykorzystywana do celów głupich lub niecnych, ale nie jest to argument przeciwko postępowi w technice.

${ }^{3}$ Jest też zapewne oddziaływanie zwrotne. Ludzie - ogłupieni reklamami i konsumpcyjnym klimatem kulturowym - dążą do posiadania przeróżnych „gadżetów”, czyli zaspokojenia coraz liczniejszych, coraz bardziej osobliwych, by nie rzec „dziwacznych”, potrzeb, a przez to rozkręcają postęp technicznych w szczególnie modnych dziedzinach. 


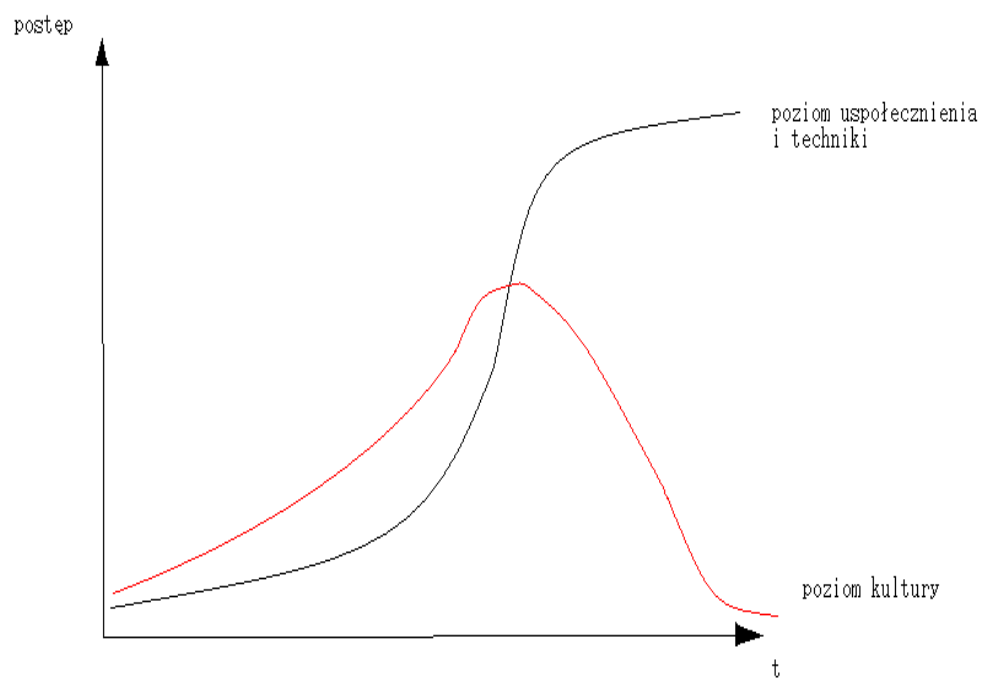

Druga możliwość: zależność ta ma charakter tymczasowy i może zostać odwrócona. Rozwój sfery techniczno-cywilizacyjnej nie musi prowadzić z konieczności do pogłębiania się kryzysu w kulturze, obecna tendencja może zostać zahamowana i strzałka poziomu kultury zacznie rosnąć. Wskazać można by tu na pewien mechanizm, który daje znać o sobie w przypadku konkretnych wynalazków technicznych; wynalazki te przez jakiś czas obniżają poziom artystyczny $\mathrm{w}$ danej dziedzinie; potem jednak, kiedy wynalazek zostanie przyswojony i „oswojony”, prowadzi to do „erupcji twórczości”, do wykorzystywania nowych możliwości i odkrywania nowych „przestrzeni”. Weźmy choćby, dla przykładu, przejście od kina niemego do kina dźwiękowego. Początkowo artystyczny poziom produkcji filmowej się obniżył; monumentalne dzieła kina niemego zostały zastapione płytkimi musicalami. Z czasem jednak również w kinie dźwiękowym zaczęły powstawać dzieła wybitne. Podobne zjawisko obserwujemy teraz, wraz z pojawieniem się filmów trójwymiarowych; filmy te opierają się przede wszystkim na trickach, efektach. Jest to zresztą najpewniej tendencja uniwersalna: twórca otrzymujący nowe narzędzie pragnie odbiorcę zafascynować samą nowinką techniczną, a nie wartością estetyczną dzieła. Idzie więc „na 
skróty", bo to łatwiejsze; po drugie zaś trzeba czasu, aby nowe narzędzie zastosować do bardziej wyrafinowanych „konstrukcji”. Wykorzystuje zatem to, co pierwsze rzuca się oczy, co najlepiej „się sprzedaje”; a jest to zwykle banalne i artystycznie jałowe.

Problem z opanowaniem nowej techniki dostrzec można również w twórczości literackiej. Pisarze XIX-wieczni $\mathrm{z}$ wielkimi oporami akceptowali maszynę do pisania (pisali piórem, a następnie, ewentualnie, przepisywali tekst na maszynie; maszyna utrudniała im pisanie, pętała myśl); podobnie XX-wieczni pisarze, przyzwyczajeni do pisania na maszynie, $\mathrm{z}$ oporami akceptowali komputerowe edytory tekstu.

Być może więc cała współczesna rewolucja technologiczna i informatyczna jest taką gigantyczną maszyną do pisania, którą ludzkość musi opanować, na której musi nauczyć się pisać tak, aby nie pętała twórczej myśli. A wtedy pisać i tworzyć będziemy lepiej: więcej i klarowniej.

Muszę przyznać, że ta druga, niefatalistyczna możliwość jest mi bliższa; jest - krótko mówiąc - bardziej prawdopodobna (choć nie można wykluczyć spełnienia się czarnego, Witkacowskiego scenariusza). Bardziej prawdopodobna nie tylko $\mathrm{z}$ powodu opisanego wyżej mechanizmu, ale również dlatego, że nietrafny jest - jak sądzę determinizm historiozoficzny. Ludzie są wolni i nieobliczalni (podmiotowość ludzka i wolność wyboru nie jest złudzeniem) oraz mądry bywa człowiek po szkodzie. Skoro więc zdiagnozujemy chorobe kultury i rozpoznamy jej źródła, to być może uda się znaleźć środki zaradcze, czyli leki. Tekst ten traktuję jako malutki przyczynek do takiego dzieła naprawczego.

Przejdźmy zatem do genezy choroby. Sądzę, że są dwie główne przyczyny prowadzą-ce do kryzysu kultury; obydwie związane - choć nie $\mathrm{w}$ jednakowym stopniu $-\mathrm{z}$ postępem technologicznym; pierwsza przyczynę określiłbym jako „oddziaływanie silne”, drugą jako „oddziaływanie słabe”. Zacznijmy od głównej przyczyny, głównego mechanizmu, czyli oddziaływania silnego.

Składają się nań, po pierwsze, demokratyzacja w sferze kultury i polityki; proces ten narastał $\mathrm{w}$ Europie od rewolucji francuskiej $\mathrm{i}$ przyśpieszył pod koniec XIX wieku wraz z rewolucją przemysłową i industrializacją. Nagle - jak pisał Ortega y Gasset - zrobiło się tłoczno, „wyroiły się tłumy” " . Poczęły zanikać, w sferze kultury, tradycyjne mecenaty: króla, arystokracji, mieszczaństwa oraz - wraz z upadkiem

${ }^{4}$ Por. J. Ortega y Gasset, Bunt mas, tłum. P. Niklewicz, Muza, Warszawa 2006. 
socjalizmu - państwa. $\mathrm{Na}$ ich miejsce, $\mathrm{z}$ coraz większym impetem, wkraczał mecenat mas.

Od kiedy zaś przemiany technologiczne, związane $\mathrm{z}$ rewolucją informatyczną, umożliwiły precyzyjne obliczanie efektów przekazu danych informacji (czyli pomiar reakcji odbiorców), mecenat mas jest sprawowany $z$ wielką precyzją. Demokratyzacja - zarówno w sferze polityki, jak i kultury - prowadzi do tego, że każdy głos jest równo liczony (profesora $i$ analfabety). W sferze polityki jest to anonimowy głos wyborczy, w sferze kultury zaś są to pomiary oglądalności, czytelnictwa, a w najnowszej wersji - liczba „kliknięć”. Jaki jest skutek mecenatu mas? Otóż wygrywają gorsze przekazy; gorsze przekazy wypierają lepsze przekazy (co przypomina ekonomiczne prawo Kopernika, że gorszy pieniądz wypiera lepszy pieniądz).

Cały ten mechanizm ilustruje prosty schemat:

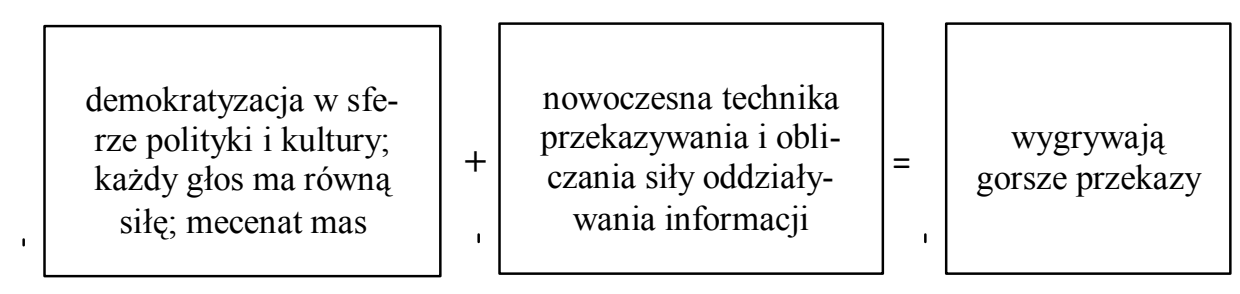

Dlaczego jednak gorsze przekazy wygrywają i wypierają lepsze? Dlaczego mamy do czynienia $z$,inflacyjnym” charakterem mediów? Dlaczego kultura masowa (rozlewająca się coraz szerszą falą dzięki nowoczesnym, coraz bardziej „inwazyjnym”, środkom przekazu) oparta na precyzyjnie mierzonych preferencjach masowych odbiorców obsuwa się - zaryzykujmy mocne określenie - w barbarzyństwo?

Na owo barbarzyństwo składa się wypieranie słowa przez obraz, wypieranie obrazów łagodnych przez obrazy drastyczne. W sferze informacyjnej dobra wiadomość to zła wiadomość, a zatem wyobraźnia czytelników gazet i odbiorców różnych programów informacyjnych jest karmiona katastrofami naturalnymi i nienaturalnymi: wypadkami lotniczymi, lądowymi i wodnymi, wojnami, zamachami, szczególnie krwawymi zbrodniami, aferami korupcyjnymi, podsłuchowymi, perwersją seksualną, dzieciobójstwem itp. W sferze rozrywkowej również dominuje przemoc i seks (ukazane hipernaturalistyczne) oraz przeróżne teleturnieje i kabarety. Wyobraźnia odbiorców przyzwyczaja się jednak do bodźców, konkurencja wymaga zatem „podkręcania potencjometru” i zwiększania „siły rażenia” przekazu, w ten sposób - w 
wyniku konkurencji i (powtórzmy) precyzyjnego mierzenia reakcji odbiorców - brutalne jest wypierane przez jeszcze bardziej brutalne, jaskrawe przez jeszcze bardziej jaskrawe, a głośne przez hałaśliwe. Znika refleksyjność, wysoki poziom artystyczny, humor ,z cicha pęk"; odbiorcę zalewa i kształtuje - w wyniku jego własnych wyborów barbarzyńska fala.

Powtórzmy jednak pytanie: dlaczego tak się dzieje? Dlaczego ludzie wybierają gorsze przekazy? Odpowiedzią i wyjaśnieniem może być krótka uwaga Czesława Miłosza (mająca w tle pesymistyczna antropologię): „Jeśli w człowieku mieszka mędrzec i idiota, kto schlebia idiocie, wygrywa" ${ }^{5}$. Podobnie pesymistyczna antropologia - nie mająca wszakże, jak u Miłosza, tła biblijnego - pojawia się już u zarania filozofii. Pitagorejczycy główny wybór, główne rozdroże w ludzkim życiu, ukazywali za pomoca, ipsylonu, litery Y. Albo idzie się w kierunku wygody, dogadzania sobie, rozpusty - co prowadzi do zamroczenia umysłu i buty (hybris) - albo idzie się w kierunku ascezy, walki z pobudkami ciała i ze słabością ducha, w kierunku jasności, harmonii, rozumności. To pierwsze jest łatwe, jak schodzenie z góry, to drugie trudne, jak droga pod górę. Nie należy jednak demonizować tych, którzy schlebiaja , idiocie w człowieku”. Albowiem - jak pisze Miłosz to „kalkulatorzy”, którzy „obsługują” zainwestowany w media kapitał. Podobny proces psucia, związany z postępem technologicznym, można zaobserwować, powtórzmy, w sferze politycznej. Rozrasta się demokracja medialna; poważna debata polityczna zanika, politycy tworzą przeróżne polityczne spoty reklamowe; dominuje w nich schlebianie przeciętnemu wyborcy i brutalne atakowanie przeciwnika (argumenty wypierane sa przez wyzwiska i przezwiska). Prowadzi to podobnie jak w sferze kultury - do psucia elit. Lepsze elity - kulturowe i polityczne - sa wypierane przez gorsze elity. Wygrywa w kulturze masowej i w polityce szeroko rozumiany populizm, w obydwu dziedzinach pojawia ochlokracja ${ }^{6}$.

Tyle o oddziaływaniu silnym, masowym; przejdźmy teraz do oddziaływania słabego.

\footnotetext{
${ }^{5}$ Th. Merton, Cz. Miłosz, Listy, Znak, Kraków 2003, s. 97.

${ }^{6} \mathrm{O}$ pojawiającej się ochlokracji w kulturze pisał już, tuż po pierwszej wojnie światowej, Florian Znaniecki. Por. F. Znaniecki, Upadek cywilizacji zachodniej, [w:] Pisma filozoficzne, t. 2, PWN, Warszawa 1991, s. 1001-1024. Różnie to zresztą wygląda w różnych krajach europejskich. W Niemczech, na przykład, poważna debata polityczna nie zanikła.
} 


\section{Zanik Metafizycznego Poczucia Dziwności Istnienia - przyczyny}

Chciałbym zacząc od pewnej deklaracji ideowej i zarazem poglądu, który znajduje się - niczym aksjomat - u podstaw niniejszych rozważań. Uważam mianowicie, że poziom elit decyduje w znacznym stopniu o poziomie społeczeństwa; jestem więc zwolennikiem elitaryzmu; jednak nie w sensie aksjologicznym (podziału ludzi na lepszych i gorszych), ale w sensie opisowym (elity decydują o kształcie mas, elity „rzeźbią” masy). Społeczny Lewiatan myśli i tworzy elitami; elity to jego umysł. Jednym ze składowych kryzysu kultury jest więc problem $\mathrm{z}$ wyłanianiem elit. Powtórzmy, elity polityczne i elity związane z kulturą masową są dzięki technice obliczeniowej - precyzyjną emanacją mas, a zatem elity kształtuje gust masowy, z kolei te coraz gorsze elity kształtują (zwrotnie) gust masowy i w ten sposób - ujmując rzecz dosadnie - coraz głupsze masy wyłaniają coraz głupsze elity, które czynią masy jeszcze głupszymi.

Elity to jednak nie tylko elity polityczne i „showmańskie”, ale też inne elity; to najzdolniejsi i najwrażliwsi ludzie $\mathrm{w}$ danym pokoleniu, których oddziaływanie nie jest tak spektakularne jak elit ukształtowanych przez masy, ale w dłuższym czasie ważniejsze. Owi najzdolniejsi tworzą ważne dzieła w sferze kultury wysokiej: nauki, sztuki, filozofii, religii. Tutaj, rzecz jasna, również pojawia się problem z odkrywaniem najzdolniejszych i dawaniem im możliwości tworzenia, a zatem problem wyłaniania elit w kulturze wysokiej; problem ten jednak pominę. Chciałbym skoncentrować się na ogólnym klimacie kulturowym, który utrudnia wzrost, dojrzewanie i rozkwit - niejako osiaganie entelechii - przez tych najzdolniejszych w danym pokoleniu; owej, rzec można, naturalnej elity. I tutaj pojawia się, wspomniane już, oddziaływanie słabe - coś co napędza kryzys kultury poprzez uderzenie wprost $\mathrm{w}$ naturalne elity duchowe, w najzdolniejszych, w najbardziej twórczych i wrażliwych, utrudniając ich dojrzewanie i owocowanie tytułowy zanik uczuć metafizycznych.

W ten sposób ponownie wracamy do Stanisława Ignacego Witkiewicza, który chyba jako pierwszy dostrzegł to zagrożenie. Jego katastrofizm kulturowy był oparty na przekonaniu, że zanik Metafizycznego Poczucia Dziwności Istnienia doprowadzi do zaniku sztuki, religii i filozofii, czyli końca ludzkości jaką znamy, ludzkości zmagającej się $\mathrm{z}$ tajemnica bytu; zastąpi ją ludzkość szczęśliwa, przypominająca pasące się - na bezpieczniej i urodzajnej łące - krowy. Zanik uczuć metafizycznych łączy on, powtórzmy, z uspołecznieniem i 
uważa, że procesy te osiagną swoje apogeum (poziom uczuć metafizycznych zero, a uspołecznienie homogeniczną nieskończoność). Od diagnozy i prognozy Witkacego mija właśnie stulecie (twierdził, że zręby tej koncepcji pojawiły się jeszcze przed pierwszą wojną i rewolucją bolszewicką, w roku 1913). Pogląd Witkacego wydaje się - w ogólnych zarysach - trafny, jednak jego diagnoza wymaga uszczegółowienie (uwzględnia nowych danych historycznych) a jego prognoza idzie zbyt daleko i jest zbyt pesymistyczna. Przyjrzyjmy się temu bliżej.

Witkacy przewiduje zanik Metafizycznego Poczucia Dziwności Istnienia. Czym jednak jest to poczucie? Ma ono - jak sądzę - kilka odmian.

Pierwsza to zdumienie i zachwyt pięknem świata. Wyobraźmy sobie wędrowanie całe życie pustynią i nagłe odkrycie oazy. Być może Ziemia jest taką oazą w pustynnym wszechświecie? Być może ten wszechświat jest taką oazą w nicości? Ten typ poczucia dziwności istnienia, oparty na zachwycie, prowadzi do różnych odmian filozoficznego i religijnego pan-teizmu.

Druga odmiana to zdumienie i przerażenie złem $\mathrm{w}$ świecie. Wyobraźmy sobie całe życie spędzone w pałacu otoczonym pięknymi ogrodami i nagłe wyjście poza jego mury; a tam żebracy, kalecy, brud, rynsztoki. Ten typ poczucia dziwności istnienia - oparty na przerażeniu światem i odrazie wobec świata - prowadzi do różnych odmian filozoficznego i religijnego skrajnego pesymizmu i manicheizmu (ontologizacji zła).

Trzecia odmiana to trwoga, trudne do wyrażenia poczucie, że nic nie jest takie, jakie jest; że nasze zwyczajne postrzeganie świata zawiera w sobie jakiś fundamentalny błąd; że za zasłoną zjawisk coś się czai, coś bezkształtnego i demonicznego; że byt „się sroży”. Poczucie to bywa określane jako niepokój metafizyczny, czy też - ogarniający całe istnienie - lęk metafizyczny.

Dodajmy do tego czwartą, egzystencjalną odmianę poczucia dziwności istnienia. Tym razem dziwności własnego istnienia. To poczucie złożone; składa się nań zdumienie, że jestem, choć mogłoby mnie nie być oraz że ,ja jestem ja" (zdumienie tożsamościa), że pojawiłem się $\mathrm{w}$ danym czasie i $\mathrm{w}$ dany miejscu, a nie kiedy indziej i nie gdzie indziej. Zdumienie, że trwam. Skąd ta ciagłość tożsamości, skoro moje ciało i myśli zmieniają się z każdą chwilą? Witkacy - podkreślając 
wagę tego poczucia - stwarza swoisty termin, który z nim wiąże: pojęcie Tożsamości Faktycznej Poszczególnej ${ }^{7}$.

Owa trzecia odmiana prowadzi nas - z zapośredniczeniem czwartej do piątej, kluczowej, odmiany Metafizycznego Poczucia Dziwności Istnienia: zdziwienia, że jest coś, a nie nic. Wyrazem tego jest słynne pytanie Leibniza: dlaczego istnieje coś, zamiast by raczej nic nie istniało, zważywszy, że nic jest łatwiejsze niż coś ${ }^{8}$. Zdziwienie to bywa określane - dla odróżnienia od zdziwień pomniejszych - jako zadziwienie bytem.

Skoro z grubsza określiliśmy, czym jest MPDI, możemy teraz rozważyć, jakie są przy-czyny jego słabnięcia i zanikania. Witkacy wskazywał przede wszystkim na wzrost uspołecznienia, stabilizacji i zamożności. Chciałbym dodać kilka innych przyczyn, które - jak sądzę działają we współczesnym zachodnim świecie.

Zacznijmy od przyczyny być może najważniejszej. Przyczyną tą jest użyjmy określenia Józefa Czapskiego - „zapomnienie o śmierci”". Śmierć zostaje wyparta ze zbiorowej wyobraźni i świadomości (antropologowie kulturowi mówią o „tabuizacji śmierci”). Symptomatyczne jest zanikanie obyczaju, aby czuwać przy nieboszczyku $\mathrm{z}$ otwartą trumną. Zapomnienie o śmierci uderza ze szczególną mocą w dwie odmiany uczuć metafizycznych; po pierwsze, w zdumienie i przerażenie złem w świecie; po drugie, w niepokój, lęk metafizyczny. Czyli w poczucie, że „coś tu nie gra”, że - powtórzmy „nic nie jest takie, jakie się zdaje”, że „być może świat jest gigantyczną pułapką". Niepokój ten zaś (jak zauważył Martin Heidegger) wiedzie nas do owego kluczowego zdziwienia i pytania metafizycznego: dlaczego

\footnotetext{
${ }^{7}$ Witkacy bywa określany jako epigon Młodej Polski, wydaje się jednak, że można go również postrzegać jako prekursora egzystencjalizmu, o czym pisał Roman Ingarden. „Był w tym wszystkim, w zasadniczej swej postawie, egzystencjalistą na wiele lat przed ukazaniem się tego kierunku we Francji, a prawdopodobnie współcześnie z wystąpieniem Heideggera”. R. Ingarden, Wspomnienie o Stanistawie Ignacym Witkiewiczu, [w:] Stanisław Ignacy Witkiewicz. Człowiek i twórca. Ksiega pamiatkowa, red. T. Kotarbiński, J. E. Płomieński, PIW, Warszawa 1957, s. 175.

${ }^{8}$ Witkacy ujmuje to podobnie: „Dlaczego w ogóle coś jest? Mogłaby przecież być Absolutna Nicość, niewyobrażalna nawet w postaci pustej przestrzeni, bo przestrzeń jest tylko jedną z dwóch stron dwoistej formy Istnienia, a nie Nicości?". S. I. Witkiewicz, Nowe formy w malarstwie $i$ wynikajace stad nieporozumienia", Wydawnictwo FiS, Skierniewice 1992, s. 9.

9 Józef Czapski dostrzegł tę nową wówczas „tendencję kulturową” podróżując na początku lat pięćdziesiątych po Stanach Zjednoczonych. Nasza cywilizacja - pisał to „,cywilizacja, która śmierci widzieć nie chce, zapomina o niej... Ta cała [religijna] wielkość i groza samego istnienia w kategoriach zła i dobra, winy i kary stwarzała wielkość i grozę śmierci... Ukradziono śmierć człowiekowi”. J. Czapski, Wyrwane strony, „Zeszyty Literackie” 1993, nr 44, wyd. II, s. 69, s. 50.
} 
jest raczej coś niż nic?. A skoro jest coś, do pytania o sens całości: bytu i życia ludzkiego. Gdyby bowiem ludzie żyli na ziemi wiecznie, gdyby nie było śmierci, to najpewniej nie pojawiłoby się pytanie o sens życia. Pytanie o sens życia powiązane jest ze świadomością jego kresu, jego skończoności. Jeśli będę zawsze, to znika pytanie o cel, punkt dojścia, które jest silnie związane z pytaniem o sens. Co więcej, bycie zawsze wydaje się oczywiste, krótka zaś wizyta $\mathrm{w}$ jakimś miejscu narzuca wręcz pytanie: „co ja tu robię?”, „po co się tu znalazłem?” (w sposób dobitny wyraził to Pascal w słynnej myśli o "straszliwej wyspie”" ${ }^{10}$ ). Kiedy zapominamy o śmierci, zadomawiamy się $\mathrm{w}$ świecie, ulegamy złudzeniu, że będziemy tu zawsze; istnienie nasze i świata zaczyna wydawać się oczywiste, znika zatem zdziwienie i - powtórzmy - pytanie o sens.

Ludzie - posłużmy się starą alegorią - zajmują miejsce pośrednie między zwierzętami i aniołami. Zwierzęta są śmiertelne, ale nieświadome (między innymi własnej śmierci), anioły mają świadomość, ale są nieśmiertelne. W człowieku spotyka się świadomość i śmiertelność, co skutkuje zdumieniem, namysłem i twórczością, ale i cierpieniem. Zapomnienie o śmierci, zmniejsza poziom uczuć metafizycznych i - przywołajmy motto z Witkacego - „czyni nas bardziej podobnymi do zwierząt niż nam się wydaje". Warto też przypomnieć pogląd Jaspersa, że sytuacje graniczne, a szczególnie zetknięcie ze śmiercią, wybijają nas z rutyny i rodzą namysł metafizyczny. Leszek Kopciuch słusznie zauważył, że Witkacy mylił się twierdząc, że sam wzrost uspołecznienia, społecznej harmonii i komfortu jest w stanie zlikwidować „metafizyczne obawy i oczekiwania” człowieka, albowiem „ludzka skończoność i śmiertelność, trzyma się twardo, i nie poddaje się wpływom ludzkiej wiedzy i technicznej władzy"11. Zaiste, marzenia o unieśmiertelnieniu człowieka poprzez naukę (na przykład Fiodorowa) okazały się mrzonką. Niemniej jednak można zlikwidować śmierć przez zapomnienie o niej, niemyślenie o niej, odwrócenie się od niej. Współczesna kultura wydaje się mieć w tym miejscu „czarną plamkę”. Brakujący element w układance Witkacego sam się wypełnił.

Kolejna przyczyna zanikania MPDI to „świat prefabrykowany”. Zacytujmy Gadamera: „Żyjemy w nowoczesnym świecie przemysłowym. A ten świat nie tylko zepchnął na margines naszej cywilizacji widzialne formy rytuału i kultu, ale uczynił jeszcze więcej - zniszczył rzecz... Nie

\footnotetext{
${ }^{10}$ B. Pascal, Myśli, tłum. T. Boy-Żeleński, PAX, Warszawa 1989, s. 197-198 [393].

${ }^{11}$ Por. L. Kopciuch, Katastrofizm S.I. Witkiewicza, „Lumen Poloniae” 2008, nr 2, s. 87.
} 
ma już rzeczy... Są egzemplarze, które można dowolnie często nabywać, bo są dowolnie często wytwarzane... Ale nie doświadczamy w nich rzeczy. Nie uobecnia się w nich nic, co nie dałoby się zastąpić, ani trochę życia, nic z dziejów... Każde dzieło sztuki jest jeszcze czymś takim, czym była kiedyś rzecz, w czego istnieniu rozbłyskuje i potwierdza się porządek $^{12}$.

Gadamer wskazuje tu na pewien kluczowy moment. Rzecz, posiadająca swoiste, niepowtarzalne „linie papilarne” - czy to wyrzeźbione przez naturę, czy też przez człowieka (a niekiedy „rzeźbiona” przez pokolenia ludzi; jak klęczniki w starych kościołach) - niejako rozbłyskuje i wskazuje na „metafizyczny porządek” bytu ${ }^{13}$. Wskazując zaś przyczynia się do metafizycznego zdziwienia, że byt nie tylko jest, ale też, że jest ładem, a nie chaosem (chaos wszak - trawestując Leibniza - jest łatwiejszy niż ład).

Podsumowując ten wątek, rzec można, że kokon cywilizacji i techniki, coraz grubszy, ułatwia życie, ale też oddziela nas od natury, od bytu (co mogłoby być dodatkowym argumentem na rzecz tezy, że postęp techniczny generuje kryzys kultury). Zaiste, ludzie dawniej dużo częściej stykali się $\mathrm{z}$ przedmiotami niepowtarzalnymi, zarówno $\mathrm{w}$ kontakcie $\mathrm{z}$ natura, jak i w kontakcie z ludzkimi wytworami. Obecnie, w świecie przemysłowym, znikają obszary „dzikiej natury” (otoczeniem ludzkim jest „natura przystrzyżona”); jesteśmy też otoczeni wytworami produkcji wieloseryjnej o bliskiej zeru odmienności między poszczególnymi egzemplarzami. Pojawia się $\mathrm{w}$ ten sposób monotonia; nasze oczy nieustannie stykają się z identycznymi obiektami. Nawet różnorodność współczesnej architektury jest podszyta ową monotonią (domy ze szkła i plastiku, mimo różnych kształtów, są do siebie podobne). Świat jest więc coraz bardziej wygodny, ale też jałowy. W istnieniu rzeczy rozbłyskuje i potwierdza się porządek, natomiast w istnieniu prefabrykatów nie rozbłyskuje i nie potwierdza się porządek. Uderza to szczególnie w metafizyczny zachwyt nad pięknem świata, ale też zmniejsza zadziwienie, że jest.

12 H. S. Gadamer, Rozum, stowo, dzieje. Szkice wybrane, thum. M. Lukasiewicz, K. Michalski, PIW, Warszawa 2000, s. 139.

${ }^{13}$ Norwidowi brakowało w Ameryce „starych kamieni”, czyli właśnie tak pojętych rzeczy. Pisał w liście: „Słowem, jednego razu czułem się tu bardzo opuszczonym. Wszędzie albowiem indziej sieroce życie moje podpierałem przynajmniej fundamentami historyi, i gruzy Rzymu często mi familijne zastępowały uczucia - tu więc, i w tem jeszcze zdradzony będąc, zatęskniłem był raz przynajmniej do jednego kilkunastowiecznego kamienia" [wyróż. J.B.]. https://archive.org/stream/chimeraa08przeuoft/chimeraa08przeuoft_ djvu.txt [dostęp: 5 czerwca 2015]. 
Co więcej, obecnie owo „odgrodzenie od bytu” ma jeszcze jedną lawinowo wręcz narastająca - przyczynę; rzecz znika również w tym sensie, że ludzie mają coraz częściej do czynienia z obrazkami, a obrazki te stają się coraz bardziej ruchome, żywe, wreszcie "trójwymiarowe” $\mathrm{i}$ interaktywne, czyli zamieniają się w quasi-świat, w quasi-byt, czyli $\mathrm{w}$ rzeczywistość wirtualnq.

Obrazkowość kultury masowej, będąca składnikiem oddziaływania silnego, jest też więc składnikiem oddziaływania słabego. Kultura obrazkowa i rzeczywistość wirtualna odrealnia „rzeczywistą rzeczywistość”. Im częściej zatem ludzie (zwłaszcza młodzi) przebywają w pasjonującej (,sensacyjnej”) rzeczywistości obrazkowej i wirtualnej, tym bardziej realny świat wydaje im się jałowy, nudy, bezbarwny, pozbawiony fundamentu $^{14}$. Co, rzecz jasna, nie sprzyja pojawianiu się uczuć metafizycznych.

Dodajmy, że silne oddziaływanie wpływa na słabe oddziaływanie czyli przyczynia się do zaniku Metafizycznego Poczucia Dziwności Istnienia - w sposób całościowy. Mówiąc w wielkim skrócie, kultura masowa, szczególnie jej gałąź rozrywkowa („,cały ten zgiełk”), działa antyrefleksyjnie i zagłusza subtelne metafizyczne tony. Rozrywka ma bowiem w swojej istocie (co znajduje odzwierciedlenie w etymologii) rozerwanie, rozproszenie, anty-skupienie ${ }^{15}$.

\footnotetext{
${ }^{14}$ Ilustruje to pewien żart: „Włączam komputer, wracam do rzeczywistości”.

${ }^{15} \mathrm{~W}$ języku francuskim rozrywka, divertissement, to oddalenie, odciagnięcie, rozproszenie. We Francji też powstała, już w XVII wieku, wnikliwa analiza rozpraszającej funkcji rozrywki, mająca w tle ,zapomnienie o śmierci”. Zacytujmy: „Skąd pochodzi, iż ten człowiek, który dopiero co stracił jedynego syna, i który przygnieciony procesami i kłopotami, dziś rano był jeszcze tak stroskany, nie myśli o tym w tej chwili? Nie dziwcie się: cały jest pochłonięty myślą, którędy przejdzie dzik, którego psy ścigają z takim zapałem od sześciu godzin. Nie trzeba więcej! Choćby człowiek najbardziej był przejęty smutkiem, jeżeli można to uzyskać, aby go wciagnać do jakiej zabawy, na ten czas już jest szczę́liwy. A znów człowiek choćby najszcześliwszy, jeśli go nie rozerwie i nie pochłonie jakaś namiętność lub zabawka, która zabroni przystępu nudzie, stanie się niebawem markotny i nieszczęśliwy. Bez rozrywki nie ma radości; przy rozrywce nie ma smutku. I na tym właśnie zasadza się szczęście osób wysokiej kondycji, iż mają mnóstwo takich, którzy ich rozrywaja, i mają możność trwania w tym stanie. Zważcie tylko. Cóż innego znaczy być nadintendentem, kanclerzem, prezydentem, jeśli nie znajdować się w kondycji, w której od rana ma się koło siebie wielką liczbę ludzi cisnących się ze wszystkich stron, aby nie zostawić ani jednej godziny w dniu na myślenie nad sobą? I kiedy taki dostojnik popadnie w niełaskę, i kiedy go odeśla do domu na wieś, gdzie nie brak mu ani dostatku, ani licznej i sprawnej służby, mimo to czuje się nędzny i opuszczony, ponieważ nikt nie przeszkadza mu myśleć o sobie.

Rozrywka jest dla ludzi światowych [wyróż. J.B.; czyli „zanurzonych w świecie”, pozbawionych „uczuć metafizycznych”] rzeczą tak potrzebną, iż bez niej czują się nieszczęśliwi; to zdarzy się im jakaś przygoda; to myślą o tym, co im się może zdarzyć; lub na-
} 
Inna ważna przyczyna zaniku MPDI wiąże się $\mathrm{z}$ rozwojem nauki nowożytnej. Nauka - posługując się Weberowskim skrótem - „odczarowuje świat”. Wyjaśniając zjawiska, zdejmuje z nich aurę tajemniczości; dziwność istnienia poszczególnych fragmentów świata zaczyna zanikać (groźna burza, z tajemniczymi grzmotami, zamienia się w banalne wyładowanie elektryczne). Nauka próbuje bowiem wyjaśniać świat przez sam świat, niewyjaśnione i tajemnicze spychając coraz dalej w szeregu przyczyn. Płodny naukowo naturalizm epistemologiczny prowadzi jednak nierzadko do naturalizmu metafizycznego (co jest uzasadnione psychologicznie, ale nie logicznie). Naukowcy (i ludzie zafascynowani nauką) chętnie więc akceptują naturalizm jako pogląd na świat. A sprowadza się to do twierdzenia, że świat jest samowystarczalny (samoistny) i samo-poznawalny ${ }^{16}$. Ruguje się $\mathrm{w}$ ten sposób tajemnicę $\mathrm{z}$ ciagu przyczyn, twierdząc, że niewyjaśniane i tajemnicze w ogóle nie występuje. Ostatecznym rozwiązaniem zagadki istnienia jest zrozumienie, że nie ma żadnej zagadki. Neopozytywista Moritz Schlick stwierdza kategorycz-

wet, gdyby nie myśleli o tym i nie mieli żadnej przyczyny do zgryzoty, nuda własną swoją mocą nie omieszkałaby wynijść z głębi serca, gdzie ma swoje naturalne korzenie, i napełniłaby duszę swoim jadem". B. Pascal, Myśli..., s. 119-212.

${ }^{16}$ Dlatego też być może naukowcy XIX-wieczni chętnie uznawali za pewnik wizję odwiecznego i niezmiennego kosmosu (jest odwieczny, a zatem fundamentalny, samowystarczalny). Pytanie „co było na początku?” otrzymuje naturalistyczna odpowiedź: „nie było żadnego początku”. Dlatego też z trudem przebijała się i wkraczała do nauki koncepcja wszechświata rozszerzającego się i koncepcja „wielkiego wybuchu” (traktowana początkowo ironicznie). Owa koncepcja oraz fizyka kwantowa (odrzucenie mechanicyzmu) zaczęły ponownie „zaczarowywać świat”. Pojawiła się szczelina, poprzez którą wnikało poczucie nieoczywistości istnienia świata. Skoro świat okazał się nie być odwieczny, do „gry” wróciło filozoficzne pytanie o początek świata i skojarzone z tym zadziwienie, że jest. Niespodziewanie jednak naturalizm metafizyczny otrzymał wsparcie ze strony fizyki kwantowej. Mam na myśli koncepcję Stephena Hawkinga, wedle której „wielki wybuch” (ze względu na skalę kwantową początku ekspansji) należy pojmować według reguł mechaniki kwantowej, to zaś prowadzi do konkluzji, że świat w czasie, podobnie jak w przestrzeni, jest skończony, ale nieograniczony. A zatem wyjściowe pytanie filozofii - „co było na początku?” - otrzymuje nową naturalistyczną odpowiedź: „mimo że świat jest w czasie skończony, nie miał początku!”. Hawking łączy to $\mathrm{z}$ uznaniem za trafną - będącej w istocie wyrazem naturalizmu metafizycznego - słabej zasady antropicznej: świat jest jaki jest (nie ma miejsca na zdziwienie metafizyczne), prawa przyrody są, jakie są; gdyby były inne, nie powstalibyśmy. Nic się za tym nie kryje. 
nie: „Nie ma żadnych "zagadek świata«" ${ }^{17}$. Ludwik Wittgenstein (wczesny) podobnie: „Wielka zagadka nie istnieje” ${ }^{18}$.

Naturalizm taki uznaje uczucia metafizyczne za bezpodstawne. Zasługują one, co najwyżej, na interpretację psychologiczną; jak przeróżne „zwidy” i „przesłuchy”. MPDI zostanie w ten sposób - jak wierzą wyznawcy tej doktryny - prześwietlone „naukowym rentgenem”, wyjaśnione i unieważnione. Ernst Mach, pozytywista starszej generacji, używa pojęcia „człowiek puszczy”. Otóż ten człowiek puszczy - który nie zapoznał się z nowożytną nauką i odczarowaniem świata - „na każdym kroku doznaje zdumienia”, zaś myśli człowieka, który dostąpił owego naukowego wtajemniczenia, ,idą za zjawiskami i prześcigaja je”. Nic go zatem nie zdumiewa, nie zaskakuje. Gdy zaś ma jakieś wattpliwości (gdy zmysłami czegoś „bezpośrednio dostąpić nie może”), „chwyta miarę i tablice logarytmiczne, które myśli jego dają podporę i ulgę"19. Dlaczego ulgę, dlaczego podporę? Może dlatego, że jednak boi się nieznanego, tajemniczego, a miara i tablice logarytmiczne upewniają go, że to lęk bezpodstawny.

I ostatnia przyczyna zaniku MPDI w kulturze współczesnej to pragmatyczne, utylitarne podejście do bytu. Nawiązując do Goethego, rzec można, że nauka dla jednych jest krową dorodną, która im masła dostarcza, dla innych jest wysoką niebiańską boginią. Nauka obecnie coraz cześciej traktowana jest jako „krowa dorodna”20. Kiedy zaś podchodzimy do rzeczy zastanawiając się, jak ją przekształcić, co z niej możemy uzyskać (,jak ją wydoić”), usuwamy w cień pytanie o jej bycie oraz zdumienie, że jest. Uczucia metafizyczne przynależą do sfery refleksyjnej, są składową vita contemplativa. Nastawienie na działania i przetwarzanie świata, olbrzymi rozrost vita activa, zagłusza i wyplenia Metafi-

\footnotetext{
${ }^{17}$ M. Schlick, Nowa filozofia doświadczenia, tłum. H. Buczyńska, [w:] H. Buczyńska, Koło wiedeńskie, Wiedza Powszechna, Warszawa 1960, s. 123.

18 L. Wittgenstein, Tractatus logico-philosophicus, thum. B. Wolniewicz, PWN, Warszawa 1970, s. 87 [6.5.].

${ }^{19}$ Por. E. Mach, Odczyty popularno naukowe, thum. Stefan Kramsztyk, Wydawnictwo Przeglądu Filozoficznego, Łódź 1899, s. 48-49: „Syn puszczy, który bystremi zmysłami swemi doskonale rozpoznać umie i wyróżniać ślady zwierzyny... Inaczej dzieje się z człowiekiem, który posiadł naszą kulturę nowoczesną.. Na czymżeż więc polega różnica obu tych ludzi? Bieg myśli pierwszego nie odpowiada rzeczom, jakie widzi. Na każdym kroku doznaje zdumienia. Myśli drugiego idą za zjawiskami i prześcigaja je, przystosowane są do rozleglejszego widnokręu ... Czuje on w myśli ogrzewanie wody w kotle lokomotywy, czuje zarazem wzmaganie się prężności, która tłok przesuwa. Gdzie bezpośrednio dostąpić nie może chwyta miarę i tablice logarytmiczne, które myśli jego dają podporę i ulgę".

${ }^{20}$ Przejawem tego jest presja na komercjalizowanie badań i odkryć naukowych.
} 
zyczne Poczucie Dziwności Istnienia. To kwestia fundamentalnego pryzmatu, przez jaki się na świat patrzy.

\section{Zanik Metafizycznego Poczucia Dziwności Istnienia - skutki}

Zdaniem Witkacego, skutkiem zaniku uczuć metafizycznych będzie zniknięcie - źródłowo w nimi powiązanych - trzech górnych pięter kultury: religii, sztuki, filozofii (czyli, używając terminologii Hegla, zanik Ducha Absolutnego). Sądzę, że Witkacy idzie w słusznym kierunku, ale idzie za daleko. Po pierwsze, poziom uczuć metafizycznych się zmniejsza, ale - jeśli wolno się tak wyrazić - nie osiaga poziomu zero. Po drugie, górne piętra kultury słabną, przeżywają kryzys, ale, jak dotąd, nie zniknęły (i chyba - jeśli nawet tendencja schyłkowa miałaby się utrzymać - daleko jeszcze do ich zniknięcia). Nie zniknięcie zatem, ale kryzys. Wracamy w ten sposób do początkowej konstatacji, że mamy w zachodniej kulturze kryzys; wracamy też do pytania, jaka miara, jakie kryterium wskazuje na jego występowanie. Czym zatem kryzys mierzymy? Najprostsze byłoby kryterium ilościowe: coraz mniej ludzi zajmuje się sztuką wyższą, coraz mniej ludzi zajmuje się filozofią, coraz mniej jest ludzi religijnych. Kryterium ilościowe bywa jednak zawodne; ilość może się nie zmieniać, a nawet rosnąć, ale jakość zdecydowanie spadać (i odwrotnie, liczba może spadać, ale jakość rosnąć). Potrzebne jest zatem - niestety mniej precyzyjne - kryterium jakościowe. Jakie zatem jakościowe kryterium wybieram? Jaką miarę? Otóż miara, którą próbuję tutaj stosować, należy do najbardziej tradycyjnych: to obiektywistycznie pojęta ( $\mathrm{w}$ duchu idealizmu obiektywnego) triada Platońska: piękno (sztuka), prawda (filozofia), dobro-zbożność (religia)21. Ktoś mógłby zauważyć - i słusznie - że sam ten wybór miary przesądza, że jeśli w kulturze zaczyna dominować relatywizm i metafizyczny naturalizm, to wskazuje to na jej kryzys. Spróbujmy jednak nie skończyć na tej konsta-

${ }^{21}$ Można zapytać, a skąd wiadomo, że ta miara jest trafna. Otóż nie wiadomo; przyjmuję to jako niedowodliwy aksjomat i traktuję hipotetycznie. Czyli, jeśli jest trafna, to mamy kryzys w kulturze; jeśli nie jest trafna, sprawa jest otwarta. Patrzę zatem na świat współczesny przez „platońskie okulary”, ale okulary te nakładam ,arbitralnie”, dokonując pewnego wyboru światopoglądowego. Nie można wszak w sposób „mocny” udowodnić trafności platonizmu, ani innego całościowego systemu filozoficznego. Filozofia jest dziedzina, w której ostateczne rozstrzygnięcia nie zapadły. Wiadomo, że Ziemia krąży wokół Słońca, a nie odwrotnie, nie wiadomo natomiast, czy wszystko się kręci wokół Boga, czy wszystko się kręci wokół natury. 
tacji, ale przyjrzeć się - patrząc przez pryzmat triady Platońskiej - temu kryzysowi bliżej.

Zacznijmy od sztuki; czyli dziedziny budzącej największe być może kontrowersje (jedni bowiem entuzjastycznie odnoszą się do jej kondycji, inni - w tym piszący te słowa - wprost przeciwnie). Rozpocząć należy od sprawy fundamentalnej. Apologeci sztuki współczesnej wskazują na jej nowatorski charakter; na poszukiwanie „nowych kanonów”, „nowych kodów”, „kodów otwartych”, na „awangardowy impet”, poszukiwanie „nowych obszarów”, nacisk na „,akt twórczy”, a nie na dzieło, na „autentyzm artystycznego wyrazu”, na jej otwarty i dialogiczny względem odbiorcy - charakter. Określenia takie powtarzają się w rozlicznych manifestach i wprowadzeniach do sztuki współczesnej, nowej sztuki. Należałoby rozstrzygnać, czy stara sztuka i nowa sztuka są ze sobą związane; czy też została, w imię radykalnej nowości i radykalnie nowych celów i kodów, zerwana ciaggłość. Czy zatem - nawiązując do Kuhna - mamy do czynienia z zupełnie nowym paradygmatem, całkowicie nieprzekładalnym na stary. Jeśli tak, to nazwa „nowa sztuka” bądź „sztuka współczesna” byłyby mylące. Nie jest to bowiem sztuka, ale coś zupełnie innego (nieprzekładalnego i nieporównywalnego); skoro zatem dla starej sztuki mamy zarezerwowany termin „,sztuka”, dla tej nowej należałby wymyślić nowy termin: na przykład „sztuczka”, albo choćby „barbabarba”. I wtedy moglibyśmy te dwie dziedziny kultury słusznie oddzielić i stwierdzić, że sztuka przeżywa kryzys, a może nawet - w duchu przepowiedni Witkacego - zanika, natomiast barbabarba ma się bardzo dobrze; nie tylko rozszerza swoje wpływy, ale - w ramach kryteriów, którym hołduje - rośnie jakościowo. Sądzę jednak, że taka wizja radykalnego zerwania i dwóch nieprzekładalnych paradygmatów nie jest trafna. Mamy zatem ciagłość i możliwość stosowania tego samego kryterium wobec sztuki dawnej i sztuki współczesnej. Nie sposób chyba jednak owych dwóch całości - ze względu na ich wielkość i złożoność zestawić ze sobą i porównać. Skazani zatem jesteśmy na punktowe wglądy. Proponuję dwa, szczególnie, moim zdaniem, dobitne.

Proponuję spacer po najlepszych muzeach $\mathrm{z}$ malarstwem średniowiecznym i renesansowym, a następnie po najbardziej modnych galeriach sztuki współczesnej: malarstwa, rzeźby i instalacji. Jakie będziemy mieli wrażenia, jak wypadnie porównanie tych dwóch estetycznych światów? Wydaje mi się (opieram się na mojej fenomenologicznej intu- 
icji związanej z ideą piękna i na moich muzealnych doświadczeniach), że doznamy szoku przejścia $\mathrm{z}$ wyżyn piękna i ładu, do nizin chaosu, brzydoty, a w tle pychy i arogancji. Jeśli to wrażenie wyda się komuś zbyt subiektywne, proponuję też dokonać - w wyobraźni, rzecz jasna pomiaru $\mathrm{w}$ perspektywie stuleci. Które $\mathrm{z}$ dzieł średniowiecznych i renesansowych będą nadal, powiedzmy, za pięćset lat, zachwycać ludzi (o ile, oczywiście, ludzkość przetrwa), czyli będą nadal w żywym kulturowym obiegu? I które dzieła wystawiane obecnie w galeriach sztuki współczesnej i awangardowej będą za pięćset lat nadal oglądane i podziwiane? Co przetrwa? Sądzę, że w pierwszy przypadku wszystko albo prawie wszystko, w drugim przypadku nic albo prawie nic. Sądzę więc, że zostanie po nas, a szczególnie po różnych awangardowych instalacjach, „złom żelazny i śmiech pokoleń”. Nie odwołuje się tu zresztą do hipotetycznych „wyroków historii”; nie traktuję historii jako ostatecznej miary prawdy, sprawiedliwości oraz piękna. Wydaje mi się po prostu, że - ujmując rzecz w dużej skali - ziarna od ewidentnych plew czas odsiewa; im dłuższy, tym dokładniej.

Drugi „punktowy” wgląd dotyczy przestrzeni rzeźbionej przez człowieka, czyli architektury. Proponuję ponownie spacer; tym razem po zachowanych starówkach miast średniowiecznych (odwiedźmy Kraków, Prage, Florencję, Siene) a następnie po nowoczesnych dzielnicach miast: po osiedlach zbudowanych $\mathrm{z}$ wielkiej płyty (w stylu Le Corbusiera), po centrach biurowo-usługowych ze szkła i metalu, po osiedlach - poustawianych w szeregi - domków jednorodzinnych. Gdzie lepiej się czujemy? W jakim otoczeniu wolimy przebywać? Dlaczego ludzie przyjeżdżający do miast ze starymi i nowoczesnymi dzielnicami zmierzają raczej do tych starych; kierują się na rynek i spacerują po wąskich i krętych uliczkach wokół rynku. Czy to tylko chęć zapoznania się z zabytkami? Nie sądzę; sądzę, że to chęć przebywania w pięknej przestrzeni. Ktoś powie, że teraz po tych uliczkach chodzi się z przyjemnością, ale w średniowieczu płynęły tam ścieki. Tak, ale to sfera techniki, a nie piękna zawartego w architekturze.

Jeśli jednak spojrzeć całościowo (co niewątpliwie grozi uproszczeniem) i pokusić się o syntezę, to wydaje się, że sztukę nowoczesną cechuje dążenie nie do piękna, ale do „zaistnienia”, a najczęściej stosowaną metodą jest szok (związany $\mathrm{z}$ tempem, $\mathrm{z}$ głośnością, $\mathrm{z}$ kontrastem, $z$ dosadnością, $z$ przemoca, brutalnością, seksem itp.). Innym chwytem jest pozorowanie głębi i mądrości (dotyczy do zwłaszcza sztuki związanej ze słowem); pojawiają się w ten sposób książki mętne, pełne uczonych terminów, zdań wielokrotnie złożonych i gwałtownych przesko- 
ków myślowych, które znajdują naśladowców. Tworzą się w ten sposób "nowe fale", rozliczne nouevau Roman, „zdekonstruowane narracje”, „poststrukturalistyczne dyskursy”; powstają góry mądrości i uczoności, które - jak radził Gombrowicz - najlepiej omijać. W sztuce elitarnej zatem, w obszarze pozorowanej głębi, nadal dobrze - jak sądzę - sprawdza się reguła Gombrowicza: „im mądrzej, tym głupiej”"22. Co ciekawe, w kulturze masowej sprawdza się odwrotna reguła: „im głupiej, tym mądrzej" (im głupiej, tym większy poklask, tym lepsza sprzedawalność i popularność).

Skoro diagnozujemy kryzys sztuki wysokiej związany z zanikiem uczuć metafizycznych i zauważamy, że głównym celem współczesnych artystów nie jest piękno, ale zaistnienie, to zapytajmy: a kto chce przede wszystkim zaistnieć? Błysnać na artystycznej agorze, zdobyć sukces, sławę i pieniądze? Otóż człowiek przyziemny, czyli pozbawiony metafizycznej wrażliwości, pozbawiony MPDI. Quod erat demonstrandum.

Kryzys filozofii nie budzi chyba tylu wątpliwości i kontrowersji, co kryzys sztuki. O kryzysie, a nawet o końcu filozofii mówią - w wielkiej liczbie - sami filozofowie. „Od stu z górą lat znaczna część akademickiej filozofii poświęca się wykazywaniu niemożliwości albo bezużyteczności filozofii, albo jednemu i drugiemu zarazem... Mnogość różnorodnych filozoficznych ścieżek zbiega się w jednym punkcie - antyfilozofii" ${ }^{23}$. Ze szczególną jednak mocą akcentuje się bezużyteczność albo nawet językową bezsensowność zwieńczenia filozoficznego gmachu, czyli metafizyki. Wszystkie działa metafizyczne - w ujęciu pozytywizmu logicznego - to nie, po prostu, twierdzenia fałszywe, ale nonsensy, czyli bełkot udający język. Głosi się więc z radością, traktując to jako objaw zdrowienia - a nie, jak Witkacy, ze smutkiem, traktując to jako objaw choroby i katastrofy - koniec metafizyki, koniec „wielkich narracji”.

Kryzys filozofii wiąże się jednak, jak sądzę, ze zjawiskiem bardziej ogólnym; z triumfem filozofii antyzdziwieniowej.

A cóż to znaczy? Źródłem filozofii - jak twierdzili Platon i Arystoteles - jest zdziwienie. Filozofia - w tym ujęciu - wyrasta $\mathrm{z}$ poczucia, że świat nie jest zwyczajny, oczywisty; że jest dziwny, zagadkowy; że za zjawiskami coś się kryje. Świat jest zadziwiająca zagadką i ta zagadka

\footnotetext{
${ }^{22}$ W. Gombrowicz, Dziennik 1961-1969, Wydawnictwo Literackie, Kraków 1997, s. 241.

${ }^{23}$ L. Kołakowski, Horror metaphysicus, Res Publica, Warszawa 1990, s. 14.
} 
domaga się rozwiązania. Jest też inne, przeciwstawne podejście do źródła $\mathrm{i}$ istoty filozofii: filozofia jest po to, aby niczemu się nie dziwić ${ }^{24}$. Świat nie jest obiektywnie dziwny i zagadkowy (jest zwyczajny, naturalny), to tylko brak wiedzy powoduje zdziwienie. Idzie więc o to, aby poprzez poznanie świata - które dokonuje się dzięki filozofii i nauce - niczemu się nie dziwić, aby nic nas nie zaskakiwało. Człowiek pozbawiony wiedzy - przywołajmy raz jeszcze Macha - „na każdym kroku doznaje zdumienia”. Myśli filozofia zaś - i jego potomka, naukowca - „ida za zjawiskami i prześcigaja je", a zatem nic go nie zaskakuje. Mamy więc dwa typy filozofii: zdziwieniową i antyzdziwieniową. Kryzys filozofii wiąże się - jak sądzę - między innymi z tym, że w ostatnich stu pięćdziesięciu latach (od końca romantyzmu) dominują w filozofii akademickiej kierunki zdecydowanie antyzdziwieniowe. Dlatego też mnogość różnorodnych filozoficznych ścieżek zbiega się w punkcie odrzucenia metafizyki.

Jakież są owe „filozoficzne ścieżki”, owe kierunki, zarazem antyzdziwieniowe i antymetafizyczne? Po pierwsze, pozytywizm w kilku swoich odmianach, scjentyzm oraz pozytywistycznie zorientowana część filozofii analitycznej. Po drugie, przeróżne wersje pragmatyzmu i neopragmatyzmu. I wreszcie, po trzecie, niezwykle szeroki nurt filozofii postmodernistycznej. W przypadku postmodernizmu sprawa jest prosta: bytu nie ma, podmiot znika; nie ma zatem ani czemu się dziwić, ani nie ma kto się dziwić. Postmodernizm jest zatem sam w sobie zadziwiający (jako niezwykle wpływowa osobliwość), ale nie ze zdziwienia wyrastający.

Podsumujmy. Triumf filozofii antyzdziwieniowej nie wskazuje, że świat nie jest zadziwiający i że tajemnica nie istnieje; wskazuje natomiast, że - niezwykle liczni obecnie - filozofowie głoszący ten pogląd, pozbawieni są zapewne Metafizycznego Poczucia Dziwności Istnienia; czyli że jego występowanie i oddziaływanie w kulturze słabnie i wpływa na kształt elit. Powtórzmy i tym razem: Quod erat demonstrandum.

Słabnięcie religii $\mathrm{w}$ świecie Zachodu jest, jak sądzę, problemem najbardziej - spośród omawianych - złożonym teoretycznie i najdonioślej-

\footnotetext{
${ }^{24}$ Pogląd ten pojawia się bodaj po raz pierwszy u stoików; niewzruszoność wszak była ich celem. Mottem filozofii antyzdziwieniowej mogłaby być rada nowożytnego stoika, Spinozy: Nec ridere, nec lugere, neque detestari, sed intelligere.
} 
szym praktycznie. Czy zatem mamy do czynienia z kryzysem religii w świecie Zachodu? A jeśli tak, to jakie będą tego skutki?

Witkacy uważał, że na fundamentalne pytania związane z niepokojem metafizycznym odpowiadała najpierw religia; straciła ona jednak wpływy na rzecz filozofii i stała się rytualną częścią kultury. Twórcze umysły przeszły do filozofii i tam poszukiwały Absolutu. Witkacy poważnie więc - jak się zdaje - traktował oświeceniowy, a następnie pozytywistyczny, schemat, w którym religia jest wypierana przez filozofię, a filozofia wypierana przez naukę. Pierwsze „wyparcie” traktował jako objaw zdrowia, drugie zaś jako zapowiedź katastrofy. Pozostał więc zwolennikiem metafizycznej fazy kultury. Rozstał się „,bez rozdzierania szat" $z$ fazą religijną, ale ze zgrozą dostrzegał nadchodzenie przyziemnej fazy naukowo-demokratycznej. Nie sądzę, aby ów schemat Comte' a był trafny, a zatem również Witkacy - o ile się w tym schemacie porusza nie ma racji. Ani odejście fazy religijnej, ani nadejście fazy pozytywistycznej, antymetafizycznej, nie jest koniecznością dziejową.

Czy zatem religia przeżywa w świecie Zachodu kryzys? Są wszak kraje, w których religia wydaje się być silna, gdzie ludzie przyznają się do wiary i chodzą regularnie do świątyń; są jednak kraje, w których religia wydaje się zanikać (Czechy, Holandia, Szwecja). Jeśli jednak szukać tendencji dominującej, to - nawet w krajach tradycyjnie religijnych wydaje się być nią sekularyzacja. Jest jednak trend przeciwny, trend powrotu do wiary, powrotu sacrum, zwany desekularyzacją. „W warunkach sekularyzacji - pisze Janusz Mariański - coraz bardziej widoczne są także procesy desekularyzacji w sensie rozwijania się autonomicznej religijności i duchowości. W Europie Bóg nie umarł - jak twierdzą krytycy religii, ale też nie jest tak żywy - jak twierdzą niektórzy teologowie i socjologowie" 25 . Fala sekularyzacji wydaje się być wszakże silniejsza niż fala powrotna, fala desekularyzacji. Co więcej, desekularyzacja dotyczy $\mathrm{w}$ mniejszym stopniu tradycyjnych kościołów chrześcijańskich, a bardziej czegoś, co bywa określane jako „Nowa Duchowość”. Chrześcijaństwo zatem, będące składnikiem fundamentu cywilizacji zachodniej mimo powrotu sacrum i „głodu Boga"26 - w Europie słabnie ${ }^{27}$. W kultu-

\footnotetext{
${ }^{25}$ J. Mariański, Sekularyzacja, desekularyzacja, nowa duchowość, Zakład Wydawniczy NOMOS, Kraków 2013, s. 26.

${ }^{26}$ „Po dziesięcioleciach postu od Boga rozwija się nowy głód Boga”. P. M. Zulehner, Teologia pastoralna wobec sytuacji Kościoła w Europie, [w:] Sytuacja Kościoła w zjednoczonej Europie, red. E. Robek, Kontrast, Warszawa 2005, s. 86-87.

${ }^{27}$ Pogląd, że zbliża się „wiosna chrześcijaństwa” wydaje się być zbyt optymistyczny. „Procesy sekularyzacji - jak pisze Jerzy Pawluczuk - nie prowadzą jednak wprost o zaniku religijności. Powodują raczej osłabienie przywiązania do wartości i wierzeń
} 
rze europejskiej mamy więc obecnie do czynienia z kryzysem sfery religijnej, a szczególnie z kryzysem chrześcijaństwa.

Czy to dobrze, czy źle? Czy słabnięcie religii jest przejawem postępu w kulturze, czy, przeciwnie, kryzysu kultury? Otóż, jak sądzę, w przypadku słabnięcia chrześcijaństwa w kulturze Zachodu, to drugie. Najprostszy argument: skoro w Biblii jest prawda, to cywilizacja, oddalająca się od Biblii, oddala się od prawdy. Argument ten zakłada jednak konfesję; spróbuję więc odwołać się do argumentów nie zakładających aktu wiary, związanych z perspektywą cywilizacyjną i egzystencjalną.

Bliskie są mi poglądy takich myślicieli jak Max Weber, Arnold Toynbee czy Christopher Dawson, którzy traktują religie jako fundament cywilizacji. Kształt i kondycja religii decyduje o innych piętrach cywilizacji. Religia, poszukując i określając ostateczną podstawę rzeczywistości, sama staje się ostateczną podstawą cywilizacji. To nie stosunki gospodarcze rzeźbią - w największym stopniu - ludzki gmach, ale religia. Jest to szczególnie widoczne w przypadku chrześcijaństwa i formowania się kultury europejskiej. To nie miecz i łopata, ale słowo (logos) - jak pisał Dawson - leży u jej posad ${ }^{28}$. Kiedy więc słabnie religia, słabnie fundament i główna siła spajająca; cywilizacja traci oparcie, zakorzenienie, staje się cywilizacją na „ruchomych piaskach”. Wiąże się to z tożsamością i spoistością; więzią społeczną w jej najogólniejszych - cywilizacyjno-kulturowych - rejestrach (,kim jesteśmy i dlaczego jesteśmy razem”). Chrześcijaństwo jest - w tej perspektywie - spoiwem (kręosłupem) i tarczą cywilizacji zachodniej. Tarcza ta może się przydać, jeśli trafny jest scenariusz „zderzenia cywilizacji”. Tak czy inaczej, przezorność nakazuje tarczę w swoim cywilizacyjnym arsenale posiadać ${ }^{29}$.

Wedle Miłosza, religia to nie tylko fundament, ale i cel. „Cywilizacja powstaje jako próba nazwania czegoś, co jest i pozostaje nienazwane. A co to jest?... Można to nazwać Absolutem, Opatrznością albo Tajemnica po prostu" ${ }^{30}$. Religie powstające spontanicznie we wszystkich kultu-

religijnych wyznawanych przez Kościoły chrześcijańskie. Faktem jest więc dechrystianizacja Europy, w mniejszym zaś stopniu jej »odreligijnienie «". W. Pawluczuk, Socjologia religii czy duchowości, [w:] J. Mariański, Sekularyzacja, desekularyzacja, nowa duchowość..., dz. cyt., s. 9.

${ }^{28}$ Por. Ch. Dawson, Formowanie się chrześcijaństwa, tłum. J. Marzęcki, PAX, Warszawa 1969 , s. 34.

${ }^{29}$ Nie zgadzam się z Nietzscheańskim poglądem, że chrześcijaństwo (akcentujące równość, litość, pokorę, ubóstwo), to religia osłabiająca cywilizację, działająca antydynamicznie.

${ }^{30}$ Cz. Miłosz, Rozmowy polskie 1999 - 2004, Wydawnictwo Literackie, Kraków 2011, s. 221. 
rach - będące podstawą i kreggosłupem kultur - to nie nieudolne (embrionalne) nauki i technologie służące do wyjaśniania i opanowywania przyrody, ale próby zrozumienia sensu świata i sensu istnienia człowieka w świecie. Poszczególne cywilizacje są więc ostatecznie próbami dotarcia do Absolutu, są próbą odsłonięcia Tajemnicy zawartej w bycie, odsłonięcia „niewidzialnej rzeczy”. Można też chyba - jeśli ten pogląd Miłosza jest trafny - stwierdzić, że „po owocach cywilizację poznacie”, czyli po kształcie Absolutu, który się z tych poszukiwań wyłania. Jakiż to Absolut wyłania się $\mathrm{z}$ poszukiwań cywilizacji chrześcijańskiej? Jak brzmi (prowizoryczne) rozwiązanie Tajemnicy bytu? Ująłbym to troiście: Bóg w swoich zasobach posiada możliwość bycia człowiekiem; Bóg jest miłością; Bóg chce, abyśmy kochali nawet nieprzyjaciół. Przyznajmy, że w kategoriach „humanistycznych” brzmi to szlachetnie i budująco. Zestawmy tę wizję Absolutu i to rozwiązanie Tajemnicy bytu choćby $z$ rozwiązaniem azteckim czy fenickim: Bóg jest żądny krwi i pragnie ofiar z ludzi. Jeśli zatem dechrystianizacja jest nie tylko chwilowym trendem wśród kilku ludów europejskich, ale trwałą tendencją cywilizacyjną, odchodzenie Zachodu od chrześcijaństwa jest odchodzeniem również od tego rozwiązania zagadki bytu, od tej wizji Absolutu. A skoro „po Absolutach ich poznacie”, to należałoby się zastanowić jakie „nowe Absoluty" - w kuźni sekularyzującej się kultury europejskiej - są obecnie wykuwane?

Wydaje się, że dwa główne. Na poziomie elitarnym, w kulturze wysokiej: nicość. Pogląd ten łączy Heideggera z postmodernistami i konsekwentnymi scjentystami takimi jak Jacques Monod. W kulturze niskiej, masowej: rzecz-produkt. Absolut ten jest wytworem nowej ideologii zwanej konsumeryzmem lub konsumizmem. Celem życia staje się konsumpcja, a szczególnie zdobywanie najnowszych modeli przedmiotów $\mathrm{z}$ różnych kategorii, co tworzy swoistą więź międzyludzką: wspólnotę konsumentów (ludzie stają się sobie bliscy, bo kupują podobne przedmioty). Powraca w ten sposób, w nowym opakowaniu, archaiczna konstrukcja myślowa, przypisująca nadzwyczajne - nadające sens życiu cechy przedmiotom martwym. Czyżby więc ludzkość (zachodnia) zatoczyła koło i wróciła do fetyszyzmu jako typu religijności? Ponownie zatem pojawia się obraz prymitywnych ludzi otoczonych produktami niezwykle zaawansowanej techniki.

$\mathrm{Na}$ zakończenie tych kilku uwag związanych z perspektywą cywilizacyjną, pozwolę sobie nawiązać do pewnego schematu historiozoficznego, który pojawia się u Bertranda Russella. „W swych początkach wielkie cywilizacje opierają się zwykle na sztywnych, pełnych przesądów 
systemach, które ulegają stopniowo rozluźnieniu, co w pewnym stadium przynosi wspaniały okres erupcji ludzkiego geniuszu - w czasie gdy utrzymują się jeszcze dobrodziejstwa dawnej tradycji, a zagrożenia związane nieodłącznie z jej rozkładem nie zdążą się jeszcze ujawnić. W miarę ich ujawniania się społeczeństwo pogrąża się jednak stopniowo w anarchii, co prowadzi, nieuchronną rzeczy koleją, do nowej tyranii tworzącej nową syntezę, której strzeże nowy system dogmatów ${ }^{31}$.

Religia jest więc - dając zbiór dogmatów - głównym składnikiem tradycji i jest, w związku z tym, powtórzmy, elementem konserwującym cywilizację, działającym na rzecz jej spójności. Kiedy ten element słabnie, cywilizacja przechodzi przez okres burzliwej twórczości, który wszakże, po przekroczeniu pewnych granic, zamienia się $\mathrm{w}$ anarchię i prowadzi do destrukcji. Cywilizacje skazane są więc na oscylowanie między Scyllą nadmiernej spójności - związanej z dyscypliną, dogmatyzmem i skostnieniem - a Charybdą dezintegracji, związanej z ekspansją indywidualizmu i egoizmu, słabnięciem religii (czyli brakiem wspólnych dogmatów), kruszeniem się więzi społecznych i zanikiem poczucia odpowiedzialności za całość. $Z$ jednej strony grozi więc skostnienie, z drugiej strony odśrodkowy rozpad spowodowany brakiem spójności, albo zewnętrzny podbój przez cywilizację bardziej zwartą. Jeśli schemat Russella jest trafny, kryzys religii w kulturze europejskiej może być zwiastunem - w długiej perspektywie - upadku tej cywilizacji.

W wymiarze indywidualnym (egzystencjalnym) religia w sposób dobitny odpowiada na pytanie o sens życia i śmierci, o ostateczną podstawę rzeczywistości. Odpowiedzi filozoficzne są zwykle słabsze, hipotetyczne oraz dające mniejsze pocieszenie. Nauka zaś takiej odpowiedzi w ogóle nie udziela, albowiem pytania o sens życia nie stawia. Wydaje się więc, że słabnięcie religii pozostawia ludzi bezradnymi wobec pytań zasadniczych; pytań o sens. Elitarna odpowiedź nihilistyczna (że trzeba pogodzić się z brakiem sensu, a co najwyżej znajdować radość w przekraczaniu granic, w transgresji) prowadzi na próg rozpaczy; zaś odpowiedź konsumeryzmu - że sensem życia jest kupowanie coraz to nowych przedmiotów, a zwłaszcza najnowszych wytworów techniki - jest zasłoną dymną, ułuda, „kiepskim opium”. Wyrazisty sens życia, podsuwany przez religię (a zwłaszcza wielkie religie monoteistyczne), daje ludziom zaufanie do bytu, poczucie bezpieczeństwa duchowego. Kiedy religia znika, obydwa te parametry się zmniejszają. Procesy desekularyzacyjne, pojawienie się „nowej duchowości”, wydaje się szukaniem jakiegoś le-

${ }^{31}$ B. Russell, Dzieje zachodniej filozofii, tłum. T. Baszniak, A. Lipszyc, M. Szczubiałka, Wydawnictwo Aletheia, Warszawa 2012, s. 20. 
karstwa, sposobu na silniejsze zakorzenienie i odbudowę ufności w życie.

Religia działa jednak niczym miecz obosieczny. Nie tylko wzmacnia poczucie sensu życia, nie tylko integruje społeczność, ale też niekiedy prowadzi do konfliktów, do nienawiści, do wojen. Niełatwo bowiem pogodzić wiarę w objawienie (w którym wszystko jest pewne i ważne; bez gradacji) $z$ postawą tolerancyjną ${ }^{32}$. Bywa też tak, że religie integrują swoich wyznawców poprzez wskazywanie wroga. „Dom pokoju” (dla współwierzących) sąsiaduje z „domem wojny”, wobec heretyków, innowierców i ateistów. Jeśli owa więź negatywna jest najważniejszym spoiwem, narasta podejrzliwość. Pytanie „»swój« czy »obcy«" staje się głównym pytaniem (nieważne mądry czy głupi, ładny czy brzydki, łagodny czy nieokrzesany); swojemu życzy się jak najlepiej, chętnie się z nim brata i zacieśnia więź; obcemu życzy się jak najgorzej; życzy mu się wojny, albo wojnę mu się wypowiada. Nałóżmy na to jeszcze jeden podział: są oto religie aktywistyczne (działające niczym środek pobudzający) i są religie tonizujące, skłaniające do refleksji i kontemplacji (działające niczym środek uspokajający).

Najbardziej niebezpieczne, jeśli idzie o owo obosieczne oddziaływanie religii, czyli jej siłę destrukcyjną, jest połączenie silnej więzi negatywnej z silnym działaniem pobudzającym. Najbardziej z kolei wskazane, jeśli idzie o budującą moc religii, o wzmacnianie spoistości społeczeństwa i poczucia sensu życia jego członków - bez agresywnych, wojennych („,toksycznych”) skutków ubocznych - jest połączenie więzi pozytywnej z pobudzaniem (w epokach wymagających przemian $\mathrm{i}$ aktywności) oraz połączenie więzi pozytywnej z uspokajaniem (w epokach w miarę stabilnych, w ,spokojnych czasach”).

Dlatego też nie należy traktować wszystkich religii identycznie i potępiać ich całościowo, jak czynią to antyteiści spod znaku Richarda Dawkinsa. Nie wszystkie religie są bowiem - jak zdają się oni sądzić - agresywne i nie wszystkie są zabobonem, który nie ma nic wspólnego z prawdą odsłanianą przez naukę (nie wszystkie religie są zatem - mówiąc dosadnie - toksyczną skamieliną, złośliwym staro-tworem, który należy jak najszybciej z ciała ludzkości usunąć). Sądzę, że należy dokonać fundamentalnego i prostego rozróżnienia; rozróżnić mianowicie religie (ew. odłamy poszczególnych religii) krystalizujące się wokół więzi negatywnej, nienawistnej oraz krystalizujące się wokół więzi pozytywnej i uniwersalnej, czyli religie radykalne i nienawistne oraz religie umiarkowa-

${ }^{32}$ Por. L. Kołakowski, Herezja, Znak, Kraków 2010, s. 68-91. 
ne, filantropijne, liberalne ${ }^{33}$. Te pierwsze powinny być krytykowane, a nawet - jeśli poziom agresji jest szczególnie wysoki - zwalczane, te drugie zaś powinny być chronione, a nawet wspierane.

Gdzie zaś należałoby umieścić główną religię kultury europejskiej i cywilizacji zachodniej, czyli chrześcijaństwo? Miało ono w swoich długich dziejach wiele rozgałęzień i różne etapy. Krytycy chętnie ekstrema i marginesy traktują jako nurt główny i istotę (wojny krzyżowe, inkwizycja, papiestwo renesansowe, wojny religijne w XVI wieku). Jeśli idzie o wątek więzi negatywnej, wzbudzania nienawiści do nieprzyjaciół, do obcych, chrześcijaństwo ma silny, w samej esencji tkwiący, bezpiecznik doktrynalny: mianowicie nakaz kochania nieprzyjaciół i nie zwalczania zła złem. Odchodzenie kaznodziei chrześcijańskich - w ostatnich dekadach - od straszenia piekłem i akcentowania bojaźni bożej, na rzecz podkreślania litościwych i miłosiernych obrazów Boga jeszcze bardziej wzmacnia nurt więzi pozytywnej; co zresztą współgra z przesunięciem akcentów z wizji Kościoła jako jedynej drogi do zbawienia na wizję bardziej otwartą, ekumeniczną ${ }^{34}$. Jeśli zaś idzie o wątek oddziaływania pobudzającego czy też uspokajającego, chrześcijaństwo, a zwłaszcza katolicyzm - patrząc w skali stuleci - stopniowo stygnie. Chrześcijaństwo działa więc coraz bardziej „tonizująco” i konserwująco, co w świecie z narastającym przyśpieszeniem historii wydaje się być szczególnie cenne, jako cywilizacyjna przeciwwaga, hamulec.

Słabnięcie chrześcijaństwa należy zatem uznać za trend niekorzystny $\mathrm{w}$ perspektywie cywilizacyjnej, tym bardziej że towarzyszy temu wkraczanie na zachodnią arenę kulturową nowych kultów. Są one nierzadko nastawione aktywistycznie; ogień wiary neofitów płonie gwałtownie, element więzi negatywnej połączony z sekciarstwem (z podziałem świata na nielicznych „,zzystych” i „swoich” oraz masy „nieczystych” i „obcych") również bywa w nich silny, co rodzi niebezpieczną mieszankę. Kulty te są też często - w sferze intelektualnej - naiwne i płytko synkretyczne (co szczególnie silnie kontrastuje z wyrafinowaną teologią katolicką i prawosławna). Pojawia się wręcz „kicz sakralny”: przeróżni szamani, wróżbici, tarociści, jogini, regresywni i transgresyjni psychoterapeuci otwierają „drzwi tajemnicy” prostym kluczem i daja niezawodną receptę na szczęście i zdrowie.

33 Piotr Gutowski rozróżnia „religijnych fundamentalistów i umiarkowanych przedstawicieli religii”, tych pierwszych nazywa „radykałami”, tych drugich religijnymi „liberałami”. Por. P. Gutowski, Czym jest „,nowy ateizm”?, [w:] Nauki przyrodnicze a nowy ateizm, red. M. Słomka, Wydawnictwo KUL, Lublin 2012, s. 8.

${ }^{34}$ Por. L. Kołakowski, Herezja..., dz. cyt., s. 85. 
Są jednak tacy, którzy z kryzysu religii w ogóle i z kryzysu chrześcijaństwa w szczególe się cieszą; uważają ten kryzys, to słabnięcie, za przejaw postępu w kulturze. Nie tylko zresztą się cieszą, ale również próbują aktywnie religię zwalczać. Mam na myśli tak zwanych „nowych ateistów", wśród których postacią najbardziej znaną jest wspomniany już Richard Dawkins ${ }^{35}$. Uważają oni, że trzeźwy rozum i prawda naukowa (opierają się oni bowiem na wierze $\mathrm{w}$ prawdę, a nie na relatywizmie epistemologicznym jak postmoderniści) powinna zastąpić „religijny fanatyzm" i „religijne zabobony”. Jest to w istocie powrót do prostego schematu oświeceniowych materialistów francuskich (jak baron Holbach czy Denis Diderot). Pomija się fakt, że prawdy naukowe nie dotyczą sfery szczególnie ważnej, związanej z pytaniem o sens; sfery zakorzenionej zresztą we wrażliwości metafizycznej. Dawkins i jego zwolennicy wydają się być tej wrażliwości pozbawieni, co zresztą wiedzie nas do tytułowej konstatacji. Akcja nowych ateistów (jak choćby tak zwana „kampania autobusowa" $\mathrm{z}$ roku 2008, atheist bus campaign) w intencji twórców ma uderzać we wszelkie religie postrzegane - bez rozróżnień - jako siły zabobonne, irracjonalne, dzielące i siejące nienawiść, terroryzm, konflikty i wojny. Nie uderza jednak w nurty religijne szczególnie agresywne, irracjonalne i fundamentalistyczne, bo ich zwolennicy są nieczuli i doskonale głusi na racjonalne argumenty antyteistów (wolno się domyślać, że terroryści inspirowani islamem nie czytają Dawkinsa). W kogo więc uderza ta akcja? W jaką przede wszystkim religię? Otóż w religię opartą na racjonalnej teologii, obudowaną wokół więzi pozytywnej, działająca (w znacznej mierze) uspokajająco oraz będącą - o czym już wspominałem - spoiwem i tarczą cywilizacji zachodniej, czyli w chrześcijaństwo. Zatem można trochę metaforycznie powiedzieć, że Dawkins, z niezwykłą pewnością siebie (i z poczuciem humoru) podcina gałąź, na której siedzi.

Nie jest to jednak główny temat tego paragrafu. Jest nim nie słabnięcie religii w ogóle, ale kryzys elit religijnych, których poziom obniża się z powodu zanikania - w kulturze współczesnej - Metafizycznego Poczucia Dziwności Istnienia. Jak jest zatem obecnie poziom elit religijnych? Jeśli idzie o instytucjonalne kościoły chrześcijańskie, a szczególnie Kościół katolicki, niewątpliwe jest ilościowe kurczenie się tej grupy; kapłanów jest coraz mniej, a seminaria odnotowują spadek chętnych. Polska jest tu - do pewnego stopnia - wyjątkiem, bo pomimo zmniejszania się liczby kleryków na tle Europy są to liczby znaczące (polscy klerycy

35 Do najbardziej znanych i wpływowych, obok Dawkinsa, należą: Christopher Hitchens, Daniel Dennett, Sam Harris, Anthony Grayling, Peter Atkins, Viktor Stenger. 
stanowią 25 procent wszystkich kleryków w Europie). Jaki jednak jest poziom tych kleryków? Oto dowiaduję się, że - wedle najnowszych badań ankietowych - co trzeci student seminarium duchownego ma kłopot $\mathrm{z}$ wymienieniem nazw trzech religii monoteistycznych, a 60 procent kleryków nie potrafi wymienić imion dwóch poprzedników Jana Pawła II. Trudno też dowiedzieć się czegoś istotnego o ich życiu wewnętrznym, albowiem odpowiadaja na pytania mechanicznie, powtarzając pewne formułki („pobyt w seminarium to przygoda z Panem Bogiem”, ,,jesteśmy w seminarium, by wzrastać w miłości") $)^{36}$. Wszystko to nie najlepiej świadczy o ogólnej wiedzy religioznawczej i humanistycznej oraz o poziomie „zindywidualizowania”. Trudno zresztą na podstawie jednego badania wyciagać daleko idące wnioski, wydaje się jednak, że spora część kleryków - zwłaszcza tych pochodzących ze wsi i małych miasteczek - motywację czerpie z tradycyjnej religijności i obyczajowości, gdzie poczesne miejsce zajmuje „strategiczny” pogląd życiowy, o którym mówi powiedzenie, że „kto ma księdza w rodzie, tego bieda nie ubodzie".

Jeśli zaś idzie o kapłanów, to można odnieść wrażenie, że coraz częściej znajdują oni zastępcze dziedziny aktywności; niezwiązane ze sferą metafizyczną, z ,tajemnicą", z wertykalnym kontaktem z transcendencją. Na to miejsce wkracza religijność horyzontalna: obrzędowość, pomaganie ludziom, akcje charytatywne, aktywność budowlana, aktywność polityczna, czy wreszcie - najmniej chwalebne - gromadzenie dóbr materialnych. Idąc zaś tropem myśli $\mathrm{H}$. Bergsona - który uważał, że najcenniejsza jest religia dynamiczna, działająca przez wielkich mistyków i proroków, mających kontakt z boskim źródłem bytu, mających zatem rozwinięte uczucia metafizyczne - należałoby zauważyć, że „horyzontalna" aktywność kapłanów cofa religię do poziomu statycznego, rytualnego i etnocentrycznego. Brak zatem elit religijnych wrażliwych na Metafizyczne Poczucie Dziwności Istnienia degeneruje religię, pozbawia ją żywej treści.

Być może więc elity nowej duchowości prezentują się lepiej i tam odnaleźć można wyższy poziom uczuć metafizycznych i wiązać z tym nadzieję na rewitalizację religii $\mathrm{w}$ europejskim kręgu kulturowym? Wszak duchowość tę cechuje „pluralizacja życia religijnego” 37 ; co więcej, „coraz wyraźniej zaznacza się [...] ewolucja od społeczno-integracyjnych

\footnotetext{
${ }^{36}$ Por. B. Strzelczyk, Rekruci Pana Boga, ,Tygodnik Powszechny” 2013, nr 19.

${ }^{37}$ Por. M. Libiszowska-Żółtkowska, Nowe ruchy religijne w globalnej przestrzeni, [w:] Religia i religijność w warunkach globalizacji, Zakład Wydawniczy NOMOS, Kraków 2007, s. $196-210$.
} 
do subiektywno-emocjonalnej funkcji religii, związanej z dystansem wobec dogmatyki i struktur hierarchicznych wielkich organizacji kościelnych" ${ }^{38}$. W nowej duchowości nie jest zatem tak ważny wątek obrzędowy, wspólnotowy, horyzontalny. Otwiera się więc pole dla „poszukiwań pionowych", dla wątku wertykalnego, dla prób docierania do transcendencji powiązanych z MPDI. Czy jednak tak się dzieje? Nowa duchowość bywa traktowana jako jeden z przejawów New Age ${ }^{39}$, który rozlewa się szeroko na różne dziedziny kultury, ale w którym występuje - jak celnie zauważył jeden z badaczy - „kurczenie się Transcendencji”40. Zaiste, w różnych odmianach nowej duchowości wyraźnie zaznaczaja się wątki immanentne, panteistyczne, sakralizujące kosmos albo ZiemięGaję (często związane z ruchami ekologicznymi). Czy zatem elity nowej duchowości prezentują wyższy poziom niż elity wielkich organizacji kościelnych? Wolno wątpić. Ujmując rzecz krótko: zważywszy na naiwność wielu (jeśli nie większości) deklaracji wiary i poglądów filozoficznych $\mathrm{z}$ tego kręgu, wydaje się, że prawdziwie wierzący $\mathrm{w}$ te deklaracje są naiwni, ci zaś, którzy naiwni nie są, posługują się nimi w celach przyziemnych. Co w obydwu przypadkach źle świadczy o wrażliwości metafizycznej.

Silna obecność wątków panteistycznych w nowej duchowości wydaje się z kolei potwierdzać tezę o wpływie zaniku uczuć metafizycznych na stan kultury. Pragnę przypomnieć, że wyróżniłem trzy główne odmiany uczuć metafizycznych: zachwyt bytem, przerażenie bytem i zadziwienie, że byt jest. Dwie ostatnie odmiany uczuć metafizycznych wydają się zaiste zanikać (między innymi z powodu „zapomnienia o śmierci" i szczelniejszego kokonu cywilizacyjnego chroniącego nas od groźnego oddziaływania natury); natomiast metafizyczny zachwyt bytem nadal oddziałuje. On zaś prowadzi do filozofii, religii i mistyki w typie panteistycznym.

\footnotetext{
${ }^{38}$ Por. J. Mariański, Sekularyzacja, desekularyzacja, nowa duchowość..., dz. cyt., s. 145.

${ }^{39}$ Por. „Zarysowanie ideologii ruchu New Age jest zadaniem trudnym. Możemy jednak wyodrębnić w nim trzy główne wymiary: pierwszy jest związany ze współczesnymi naukami przyrodniczymi, zwłaszcza z fizyką i biologią; drugi ma swe korzenie w kulturze alternatywnej, w szczególności w ruchu feministycznym i ekologicznym; wymiar trzeci można określić jako duchowy lub »religijny« w szerokim znaczeniu tego słowa, gdyż czerpie on $\mathrm{z}$ różnych źródeł: $\mathrm{z}$ astrologii, ezoteryzmu, archaicznych mitów, mądrości indiańskiej, religii Dalekiego Wschodu, a także z nauk psychologicznych". A. O. Pennesi, Chrystus a New Age, Verbinum, Warszawa 2003, s. 7. Bywa też tak, że New Age jest traktowany jako ,jeden z przejawów” nowej duchowości. Por. J. Mariański, Sekularyzacja, desekularyzacja, nowa duchowość..., dz. cyt., s. 146.

40 T. Doktór, Pluralizm religijny: New Age i fundamentalizm, „Kwartalnik religioznawczy" 2007, nr 59/60, s. 37.
} 
Kryzys religii wydaje się więc być faktem, zarówno w wersji „starej”, jak i „nowej duchowości”.

\section{Co robić?}

Jeśli powyższa diagnoza jest trafna - jeśli kultura europejska (a nawet kultura Zachodu) przeżywa kryzys, i jeśli jest on spowodowany zanikiem Metafizycznego Poczucia Dziwności Istnienia, co wyjaławia wyższe piętra kultury, czyli destrukcyjnie wpływa na działalność elit artystycznych, filozoficzny i religijnych ${ }^{41}$ - to pojawia się pytanie: co robić? Czy można jakoś tę tendencję zahamować, a nawet odwrócić? Otóż powtórzmy - jeśli diagnoza ta jest trafna, należy sięgnać do źródeł, czyli próbować zlikwidować przyczyny osłabiające występowanie MPDI w kulturze. Wymieńmy teraz, hasłowo, te przyczyny (pisałem o nich w paragrafie trzecim), wskazując zarazem pewne antidota.

Należy przeciwdziałać zapomnieniu o śmierci. Po pierwsze zatem: memento mori.

Należy zmniejszać połacie przestrzeni prefabrykowanej i próbować wrócić do rzeczy samych; należy zatem postulować odejście od standaryzacji i funkcjonalizmu w projektowaniu przemysłowym, w urbanistyce, architekturze i architekturze wnętrz. Otoczeniem człowieka powinny być w jak największym stopniu przedmioty niepowtarzane.

Należy ograniczać czas dostępu dzieci do rzeczywistości wirtualnej (dorośli zaś powinni się samoograniczyć). Należy też ograniczać siłę oddziaływania - szczególnie na ludzi młodych - kultury masowej oraz zmienić model wychowania i kształcenia masowego, w którym dominuje obecnie standaryzacja.

Należy precyzyjnie rozróżniać naukowy naturalizm metodologiczny od filozoficznego i światopoglądowego naturalizmu metafizycznego, wskazując, że nie ma logicznego przejścia od jednego do drugiego. Należy zwalczać rzekomo naukowy pogląd, że świat jest zwyczajny, że jest jaki jest (zwieńczenie „odczarowywania”).

\footnotetext{
${ }^{41}$ Nie wpływa zaś destrukcyjnie na rozwój nauki i techniki, czyli na elity naukowe, bo one działają w ramach naturalizmu epistemologicznego (który nie tylko nie wymaga uczuć metafizycznych, ale wręcz je wyklucza; ewentualnie w „nawias wrzuca” jako niepotrzebny balast) oraz modelu pracy zbiorowej, coraz bardziej zalgorytmizowanej, gdzie nie „skrzydeł trzeba, a ołowiu” metody. Nauka zatem jawi się coraz bardziej jako fabrykacja odkryć i wynalazków (co wolno chyba kojarzyć z pierwowzorem takiego podejścia, mianowicie z Baconowską „Świątynią Salomona”).
} 
Należy ograniczać - i demaskować jako nieoczywiste - pragmatyczne i manipulacyjne podejście do świata. Pytania: co moge $z$ tej rzeczy mieć?, co mogę z tej rzeczy wycisnąć dla siebie? (przechodzące nierzadko, siłą rozpędu, w podobny stosunek do człowieka), próbować zastępować pytaniem: czym rzecz jest?, cóż to jest?. Podejście aktywistyczne próbować zastępować podejściem bardziej refleksyjnym, kontemplacyjnym; próbą poznania rzeczy w jej niepowtarzalności i „w jej jestestwie” (że w ogóle jest). Należy zatem - ujmując rzecz najkrócej - przypomnieć sobie o bycie. Odnotujmy, że gorączkowa działalność, manipulowanie światem, działalność „wewnątrz-światowa” jest sposobem zapomnienia o śmierci. A zatem punkt pierwszy łączy się z punktem ostatnim.

Należy więc, mówiąc najogólniej, iść pod prąd głównym trendom w kulturze współczesnej. Dlaczego? Bo mamy do czynienia - o ile powyższe wywody są trafne - $\mathrm{z}$ kryzysem kultury.

\section{Bibliografia}

Czapski J., Wyrwane strony, „Zeszyty Literackie” 1993, nr 44, wyd. II. Dawson Ch., Formowanie się chrześcijaństwa, tłum. J. Marzęcki, PAX, Warszawa 1969.

Doktór T., Pluralizm religijny: New Age i fundamentalizm, „Nomos, Kwartalnik religioznawczy" 2007, nr 59/60.

Gadamer H. S., Rozum, stowo, dzieje. Szkice wybrane, thum. M. Łukasiewicz, K. Michalski, PIW, Warszawa 2000.

Gombrowicz W., Dziennik 1961-1969, Wydawnictwo Literacie, Kraków 1997.

Gutowski P., Czym jest „nowy ateizm”?, [w:] Nauki przyrodnicze a nowy ateizm, red. M. Słomka, Wydawnictwo KUL, Lublin 2012.

Ingarden R., Wspomnienie o Stanistawie Ignacym Witkiewiczu, [w:] Stanisław Ignacy Witkiewicz. Człowiek i twórca. Ksiega pamiatkowa, red. T. Kotarbiński, J. E. Płomieński, PIW, Warszawa 1957.

Kołakowski L., Horror metaphysicus, Res Publica, Warszawa 1990.

Kołakowski L., Herezja, Znak, Kraków 2010.

Kopciuch L., Katastrofizm S. I. Witkiewicza, „Lumen Poloniae” 2008, nr 2.

Libiszowska-Żółtkowska M., Nowe ruchy religijne w globalnej przestrzeni, [w:] Religia $i$ religijność $w$ warunkach globalizacji, Zakład Wydawniczy NOMOS, Kraków 2007. 
Mach E., Odczyty popularno-naukowe, thum. S. Kramsztyk, Wydawnictwo Przeglądu Filozoficznego, Łódź 1899.

Mariański J., Sekularyzacja, desekularyzacja, nowa duchowość, Zakład Wydawniczy NOMOS, Kraków 2013.

Merton Th., Miłosz Cz., Listy, Znak, Kraków 2003.

Miłosz Cz., Rozmowy polskie 1999 - 2004, Wydawnictwo Literackie, Kraków 2011.

Miłosz Cz., Ziemia Ulro, Znak, Kraków 1994.

Ortega y Gasset J., Bunt mas, thum. P. Niklewicz, Wydawnictwo Muza, Warszawa 2006.

Pascal B., Myśli, tłum. T. Boy-Żeleński, PAX, Warszawa 1989.

Pennesi A. O., Chrystus a New Age, Verbinum, Warszawa 2003.

Russell B., Dzieje zachodniej filozofii, thum. T. Baszniak, A. Lipszyc, M. Szczubiałka, Wydawnictwo Aletheia, Warszawa 2012.

Schlick M., Nowa filozofia doświadczenia, tłum. H. Buczyńska, [w:] H. Buczyńska, Koło wiedeńskie, Wiedza Powszechna, Warszawa 1960.

Strzelczyk B., Rekruci Pana Boga, „Tygodnik Powszechny” 2013, nr 19.

Witkiewicz S.I., Nowe formy $w$ malarstwie $i$ wynikajace stad nieporozumienia, Wydawnictwo FiS, Skierniewice 1992.

Wittgenstein L., Tractatus logico-philosophicus, tłum. B. Wolniewicz, PWN, Warszawa 1970.

Znaniecki F., Upadek cywilizacji zachodniej, [w:] Pisma filozoficzne, t. 2, PWN, Warszawa 1991.

Zulehner P. M., Teologia pastoralna wobec sytuacji Kościoła w Europie, [w:] Sytuacja Kościola w zjednoczonej Europie, red. E. Robek, Kontrast, Warszawa 2005.

https://archive.org/stream/chimeraa08przeuoft/chimeraa08przeuoft - djvu.txt 


\section{Summary \\ The disappearance of Metaphysical Feelings as a Cause of the Crisis of Culture}

In my opinion, the unquestionable progress in technology is currently accompanied by the crisis of culture in the West. What is controversial is its intensification. One may defend a view that what is developing is simultaneously partly decomposing. Thus, crisis is permanent and is a function of progress, but it is also impossible to reject the accuracy of the catastrophic diagnosis. This crisis undoubtedly manifests itself differently and has different sources. In this article I focus on the source pointed by I. S. Witkiewicz: on the disappearance of the "Metaphysical Sense of the Oddity of Existence" as well as its results. I try to apply Witkacy's diagnosis, which seems to me generally accurate, to modern times. In my opinion, the disappearance of metaphysical feelings is now stimulated by a not only increasingly convenient and hermetic "civilisation cocoon" yet also "oblivion of death" (death becomes taboo in the culture) as well as the methodological naturalism in science, which results in the world ceasing to appear "odd" or "mysterious". All this damages and "sterilizes" the upper tiers of culture, which means that it affects adversely the activities of artistic, philosophical or religious elites.

Keywords: culture, crisis, catastrophism, S. I. Witkiewicz

\section{Zusammenfassung}

\section{Das Schwinden der metaphysischen Gefühle als Ursache der Kulturkrise}

Ich stehe auf dem Standpunkt, dass den zweifellosen Fortschritt in der Technik heutzutage im Westen die Kulturkrise begleitet. Es lässt sich über ihre Kraft streiten: Man kann nämlich den Standpunkt verteidigen, dass was sich entwickelt, das zerfällt auch zum Teil, folglich ist die Krise permanent und sie ist eine Funktion des Fortschritts, aber man kann auch nicht die Richtigkeit der katastrophischen Diagnose ablehnen. Diese Krise hat unzweifelhaft unterschiedliche Anzeichen und unterschiedliche Quellen. Im Artikel konzentriere ich mich auf die von S. I. Witkiewicz aufgezeigte Quelle: auf das Schwinden des Metaphysischen Gefühls der Seltsamkeit des Daseins und auf seine Folgen. Die Diagnose von Witkacy, die mir in allgemeinen Umrissen richtig scheint versuche ich auf gegenwärtige Zeiten anzuwenden. Ich vertrete die Meinung, dass das Schwinden der metaphysischen Gefühle heute nicht nur durch einen immer bequemeren und immer dichteren "Zivilisationskokon", aber auch durch das "Vergessen des Todes" (der Tod wird in der Kultur zum Tabu) und durch das Vorherrschen des methodologischen Naturalismus in der Wissenschaft stimuliert wird. Der letzte Faktor führt dazu, dass die Welt nicht mehr "seltsam", "geheimnisvoll" erscheint. All das beeinträchtigt höhere Stufen der Kultur, macht sie "steril", beeinflusst also negativ das Wirken der künstlerischen, philosophischen und religiösen Eliten.

Schlüsselworte: Kultur, Krise, Katastrophismus, S. I. Witkiewicz 
Pobrane z czasopisma http://kulturaiwartosci.journals.umcs.pl

Data: 26/04/2023 17:04:28

73 Jacek Breczko, Zanik uczuć metafizycznych...

Note about Author:

JACEK BRECZKO, habilitated doctor, Department of Human Philosophy and Psychology, Medical University of Bialystok, Poland; address for correspondence: ul. Szpitalna 37, PL 15-295 Białystok. E-Mail: breczko@poczta.onet.pl 